\title{
Greening and Energy Issues: An Analysis of Four Canadian Newspapers
}

\author{
Gregor Wolbring ${ }^{1} \&$ Jacqueline Noga $^{1}$ \\ ${ }^{1}$ Faculty of Medicine, Department Community Health Sciences, Stream of Community Rehabilitation and \\ Disability Studies, University of Calgary, Calgary, Canada \\ Correspondence: Gregor Wolbring, Department Community Health Sciences, Stream of Community \\ Rehabilitation and Disability Studies, University of Calgary, 3330 Hospital Drive NW, Calgary, Alberta T2N \\ 4N1, Canada. Tel: 1-403-210-7083. E-mail: gwolbrin@ucalgary.ca
}

\author{
Received: May 27, 2013 Accepted: June 10, 2013 Online Published: June 24, 2013 \\ doi:10.5539/jsd.v6n7p88 URL: http://dx.doi.org/10.5539/jsd.v6n7p88
}

\begin{abstract}
The concept of greening has been part of the public discourse for some time. The greening of energy, which is seen as essential for green growth and a green economy, which in turn is seen as essential for sustainable development, is part of this public discourse. Media is seen to be important in shaping public opinion. We investigated how two national Canadian newspapers (Globe and Mail and National Post) and two regional (Alberta) newspapers (Calgary Herald and Edmonton Journal) cover greening as it relates to energy issues. The key findings were: although $88 \%$ of newspaper articles that covered greening also covered energy issues, only $0.15 \%$ of the articles that covered energy issues also contained the term greening; greening was mostly framed in economical not environmental protection terms; many themes were covered but often only once in a given article and often in less than $10 \%$ of the overall articles. This analysis could give guidance to stakeholders such as industry and non-governmental organizations on how greening is discussed in relation to energy issues. The analysis suggests that there is a need for increasing the visibility of greening in energy covering articles, that a more analytical approach is needed linking it for example to the greening indicator discourse as indicators are envisioned to give guidance as to what to do how and that a rethinking of how stakeholders distribute their greening message as it relates to energy issues might be warranted.
\end{abstract}

Keywords: content analysis, newspapers, public perception, greening, energy, media analysis

\section{Introduction}

Although there is no widely accepted definition of greening (Mair \& Jago, 2009) we understand it for the sake of this paper to mean making something more environmentally friendly. According to Young, greening is seen as a necessary action in the 21 st century (Young, 2012). Various aspects of greening have been covered in recent years such as greening industrial ecosystems (Allenby, 1994; Arnold \& Hockerts, 2010), greening of processes and systems (Dornfeld, 2010), green utopianism (Mathisen, 2006), life cycle analysis (Mitchell, 2011), entrepreneurship (Nodoushani \& Nodoushani, 2010), supply chain (Singh \& Mathur, 2011), greening being part of social responsibility (Scott, 2011), design for environment (Soylu \& Dumville, 2011), greening and developing countries (Tong, Shi, \& Zhou, 2011), and greening the economy (Young, 2011).

Greening is a topic in regards to various hydrocarbon energy sources such as coal (Stauffer et al., 2011; Sundararajan, 2008), oil (Gieg, 2011), petroleum (Islam, Chhetri, Khan, \& Islam, 2010), greening of various aspects of the oil business (Bosselman, 2011; Deng \& Liu, 2011; Dong, FAN, \& Zhang, 2011; El Chaar \& Lamont, 2010; Stanislaw, 2010) and greening electricity (Dinica, 2008). Greening of energy is seen as essential for green growth, greening growth and a green economy (OECD, 2011, 2012). The OECD proposed a set of indicators for greening and green growth $(\mathrm{OECD}, 2011)$ that are directly pertinent to energy and greening. The United Nations Environment Program (UNEP) also works on related indicators (UNEP, 2012) and Eurostat has initiated the IGrowGreen initiative (OECD, 2011). The OECD states in a 2012 report, "Greening energy will be among the earliest drivers of greener growth. Meeting growing energy demand will mean a total investment in the sector of USD 270 trillion over the next four decades (IEA, 2010a). This potentially provides an enormous opportunity to create a more sustainable base for economic and social development. Innovative ways of providing the energy services that drive economic activities and underpin well-being in a clean and sustainable way could provide new growth opportunities, creating new businesses and jobs and offsetting losses from contracting sectors" (OECD, 2012). 
At the same time many question the legitimacy of green (Magness, 2012) and the viability of greening claims (Coppolecchia, 2010; Gallicano, 2011; Maier, 2011; Ng, 2010; Stein, 2010) (greenwashing) including the greening of the oil industry (Cherry \& Sneirson, 2010; Sneirson \& Cherry, 2011; Warner, 2008), natural gas (Stephenson, Doukas, \& Shaw, 2012) and other energy sources (Blackwell, 1997; Bruno \& Karliner, 2000; Energy Consumption Rating Initiative, 2008; Koeller \& Gauley, 2009; Pearce, 2009; Plec \& Pettenger, 2012). Media is a large and extremely influential institution. Zhao in the literature section of his 2009 article Media Use and Global Warming Perceptions lists that media are reported to shape public agenda, mold conceptions of social reality, enable behavioral acquisition through vicarious learning, and facilitate the dissemination of technological innovations (Zhao, 2009). Others highlight the ability of media to change public behavior (Abroms \& Maibach, 2008) and the public's perception and actions on a given issue (Weingart, 2012). One study found that media advocacy for a program seeking to mitigate tobacco use was effective in changing policies (Niederdeppe, Farrelly, Thomas, Wenter, \& Weitzenkamp, 2007).

Various studies addressed the influence of media on public perceptions of environmental issues.

One study suggests that the media has the capacity to influence public ideas about climate change as the news is seen to be the 'truth' (Smith, 2005). Another study found that when newspapers in Japan began to cover global warming more frequently, public concern about global warming increased comparatively (Sampei \& Aoyagi-Usui, 2009). One article that looked at the way the British press visually displays climate change (Smith \& Joffe, 2009) found three broad themes, namely impact, personification and representation of climate change. They noted that climate change was depicted as a domestic issue and not just an issue for other parts of the world, challenging the view of it being a long term and future threat (Smith \& Joffe, 2009). One PhD thesis from the United Kingdom examined "the contextual determinants and dimensions of public understanding of, and response to, climate change" (Whitmarsh, 2005). This study found that climate change was associated with ozone depletion and air pollution but not with other issues such as floods. The study found further the "salience of distrust and uncertainty in public perceptions of climate change" and a "disparity between expert and lay conceptions of climate change, and between actions prescribed by policy-makers and those taken by the public to mitigate climate change" (Whitmarsh, 2005).

As to the topic of energy within the environmental discourse, one study looking at the societal acceptance of carbon capture and storage technologies in the Netherlands found that the media reflected in a balanced way on the views of stakeholders such as industry, government, and environmental NGOs (Van Alphen, van Voorst tot Voorst, Hekkert, \& Smits, 2007). Another study looking at newspaper coverage of wind power in Texas, Minnesota, and Massachusetts found the salience of wind energy having been greater in Massachusetts than in Texas or Minnesota (Stephens, Rand, \& Melnick, 2009). One study examining the coverage of bioenergy in the news media of Norway and Sweden found that the news media in the two countries offered different imagery of bioenergy (Skjølsvold, 2012). A media study about Spanish PV solar experience concluded that media "might end up influencing Spanish public and social acceptance of PV solar and other sources of renewable energy (Heras-Saizarbitoria, Cilleruelo, \& Zamanillo, 2011).

Studies also exist in the Canadian context. A study of the influence of media on Canadian perceptions of environmental concerns investigating four newspapers (Toronto Globe and Mail, Ottawa Citizen, Vancouver Sun and La Presse), five magazines (Maclean's, Chatelaine, both French and English and Saturday Night), radio shows and television programs between 1960-1972 found that public awareness and concern for environmental issues was greatly catalyzed and maintained by the media sources (Parlour \& Schatzow, 1978). Another study, comparing the Toronto Star to the Globe and Mail on the discourse around climate change from 1988 to 2007, found that the issue was mostly portrayed as a large scale one in need of large scale solutions. The authors concluded that this might discourage the public and government from looking for solutions on regional and local levels and on the level of the individual (Ahchong \& Dodds, 2012).

One study using an actor-network theoretical approach found that "ecological footprint" as a term does not give a very strong voice to the environment as the media coverage of the term "tends to be vague" and "does not connect much to policy making or changing practices" (Petersen, 2013). One study analyzed the coverage of the health effects of wind turbines in Ontario newspapers relative to the Green Energy Act using published risk communication fright factors; the authors found that certain fright factors such as 'dread' and 'poorly understood by science' were more present than 'Involuntary exposure' and 'inequitable distribution' (Deignan, Harvey, \& Hoffman-Goetz, 2013).

As to energy issues in Canada, most of the environmental concerns are related to the extraction of energy sources such as oil and gas, and the greening of these practices is a large part of the environmental discussion (Joseph \& 
Hughes, 2006). According to Good, how climate issues are framed in Canada is useful to be studied because a) Canada emits a huge quantity of greenhouse gases; b) Canada has a very close relationship with the United States and c) as a Commonwealth country, Canada has a relatively close relationship with various members of the European Union (Good, 2008). Canada is also seen as a main player in the greening energy discourse especially around the greening of various aspects of hydrocarbon energy sources and the replacement of hydrocarbon energy sources with renewable energy sources. A press release related to a 2013 report funded by the David Suzuki Foundation, the Canadian Academy of Engineering, and the Trottier Family Foundation stated that "Canada could be the world's green-energy superpower" (Leahy, 2013; Torrie, 2013).

We performed a quantitative and qualitative content analysis of two national Canadian newspapers (Globe and Mail and National Post) and two regional (Alberta) newspapers (Calgary Herald and Edmonton Journal) around the topic of greening and energy. We were interested in the sentiment around greening, which energy sources were mentioned, who was given a voice in the media coverage and which topics were linked to greening in the articles. Our findings might be useful for groups that are interested in greening issues to reevaluate the usefulness of newspapers as a source of information and dissemination of the message.

\section{Method}

Media have the opportunity to shape public opinion by framing news in different ways (De Vreese, 2005). Our study aimed to investigate the framing of greening as it relates to energy issues in Canadian newspapers.

\subsection{Data Source}

As sources we used the National Post and the Globe and Mail, the only two Canadian newspapers with national reach, and the Calgary Herald and Edmonton Journal, two newspapers with local reach in a Canadian province where energy production is a main source of governmental and individual income; Calgary houses most of the headquarters of companies involved in energy issues, and Edmonton is the seat of the provincial government.

\subsection{Data Sampling}

In order to identify eligible articles, a keyword search was performed on January 13, 2013 using the Canadian Newsstand Proquest online database provided by the University of Calgary. The database keyword combination used was the following: Greening (in all fields and text) AND [one of the four newspapers] (exact in publication) AND energy (in all fields and text). The articles found were used for further quantitative and qualitative content analysis if they also fulfilled the following inclusion criteria: full text, newspapers only, English only. All articles that fit the inclusion criteria were downloaded as PDF's and imported into Atlas-ti.

\subsection{Data Analysis}

Framing is one way to perform a media analysis (Entman, 1991). One can seek to identify existing structural frames such as common/collective interest frame, responsibility, conflict, human interest, moralization, and economic interests (Benford, 1997), episodic and thematic frames (Iyengar, 1994), and content frames (Scheufele, 1999). We cover in our analysis issue-specific media news frames that are communicated to the reader (De Vreese, 2005).

Ahchong and Dodds in their article "Anthropogenic climate change coverage in two Canadian newspapers, the Toronto Star and the Globe and Mail, from 1988 to 2007" (Ahchong \& Dodds, 2012) used an expanded version of the content analysis framework developed by Liu et al. (2008) who examined climate change coverage in the Houston Chronicle from 1992 to 2005. We modified the framework used by Ahchong and Dodds (2012) toward our topic of greening for which no content analysis framework currently exists in the literature.

We focused on the following:

(1) Determine the prominence (salience) of greening in the four Canadian news sources by identifying the total number of articles for each year.

(2) Examine various attributes regarding greening as they are presented in the articles: issue image (positive vs. negative), issue scope (e.g. which energy source is mentioned, what should be greened, what is the focus - local, national, international), linkage to other issues (e.g. energy, agriculture, health), and compare and contrast how they are depicted in the newspapers with local and national reach.

(3) Outline the types of procedures seen as greening and the parties that are visible in the newspapers (e.g., government, industry, environmental groups, Indigenous people, Inuit's, Inuvik, nature).

(4) Discuss how decision makers and the public may be affected by the portrayal of greening in the Canadian news media. 
We used Atlas.ti, a qualitative data analysis software (CAQDAS) (Koenig, 2004; MacMillan, 2005), for our data analysis which allows the researcher to analyze imported sources of data that can consists of PDF, Word, html, audio and video files. After we imported all our newspaper files as PDF's, we performed hermeneutical keyword coding. We employed two different coding strategies: a deductive strategy where we used a set of predetermined terms fitting the coding analytical framework we used and the research questions. The auto-code function of Atlas.ti allows one to search all documents in one go for a given word. Atlas.ti generates a list of quotations of all sentences a given searched word is present in. It also allows for the generation of a total frequency count of a given word in all documents for identifying how many sources (in our case the different PDF's containing the given word) cover the word. However this word list is bare of any context.

Therefore as a second strategy, we employed an inductive and iterative coding strategy, in which articles were read and when a theme (frame) was identified we used the free coding option to generate a phrase that represents the theme and added this phrase to the coding list. Once the coding was finished we used Atlas-ti to 1) compare the frequency of certain themes between the different newspapers (quantitative data) and 2) retrieve quotes from the newspapers for a deeper analysis (qualitative analysis). Both authors performed the coding to increase reliability, and differences were resolved through discussions.

\subsection{Limitations}

Media ownership is seen to influence news content (Anderson, 2009; Baer, Geller, Grundfest, \& Possner, 1974; Gilens \& Hertzman, 2000; Price, 2003; Schudson, 2002; Winseck, 2002). Three of our four newspapers (National Post, Calgary Herald and Edmonton Journal) are owned by the same publisher. Unfortunately the other local newspapers that are distributed in Calgary and Edmonton who have a different ownership are not available through the Canadian Newsstand database or another database available to us. News generated is also influenced by context outside the media organization (Reese, 2001). We have chosen two newspapers from a Canadian province that heavily depends on energy production. We cannot exclude that Canadian newspapers in provinces that are not exposed to energy production might portray greening related to energy issues differently. Furthermore we looked only for English language content. This means our study was not tailored to look at one province in Canada (Quebec) where the first language is French. Furthermore nowadays comments from readers often happen through the webpage of the newspapers. These comments evident on the newspaper's webpage are not present in the articles downloaded from the Proquest database. This means our study was not equipped to look at the public sentiment toward various articles based on web-based comments. This might be a possible future research angle, along with looking at French language media content.

\section{Results}

\subsection{General Overview of How Topics Are Covered in Each Newspaper}

After having applied our inclusion and exclusion criteria, 78 articles from the National Post, 194 articles from the Globe and Mail, 142 articles from the Calgary Herald and 124 article from the Edmonton Journal were analyzed for their greening content as it relates to energy issues. These articles reflected $88 \%$ of the articles in the four newspapers that covered greening period indicating that the majority of greening articles are concerned with energy issues. However on the other hand only $0.15 \%$ of the articles that covered energy in the four newspapers in general also covered greening indicating that very few energy related articles are concerned with the greening aspect. As to individual newspapers, the Globe and Mail was not focused as much on greening actions, but on the government's responsibility to produce these actions. The other national newspaper, the National Post, focused on how greening should be considered especially as an economic opportunity. Many articles discussed the new opportunities arising in the environmental sustainability field, including jobs for university students, engineers, entrepreneurs, and oil sands workers. According to an article in National Post, a survey which asked participants why they partake in greening practices found that " $55 \%$ of respondents comply with greening policies just to support corporate values, while another $23 \%$ cited financial reasons. Saving the planet came in at a lowly 8\%" (Beun-Chown, 2009). The same article contained an interview with an entrepreneur in the emerging greening field, who has created a business dedicated to teaching greening practices to individuals and companies. The person interviewed indicated that many clients coming to her were looking to save money rather than the environment (Beun-Chown, 2009).

As to the two regional newspapers, both focused more on greening of oil and natural gas extraction than the national newspapers, which is understandable given that the oil and natural gas industry is a main component of Alberta's economy. However there were other differences between the regional and national newspapers. The Edmonton Journal articles were more based on stories about those who have already gone green and experienced these economic benefits. The general tone found in the articles of the Edmonton Journal was positive on the 
topic of greening, and the discussion revolved around current greening practices and successful individuals and businesses. The positive stories and encouraging messages regarding greening in the Edmonton Journal were also found in the other regional newspaper, the Calgary Herald. The Calgary Herald offered a variety of articles which discussed current actions being taken to go green, including the best brands and companies to use when making green choices.

\subsection{Issue of Salience}

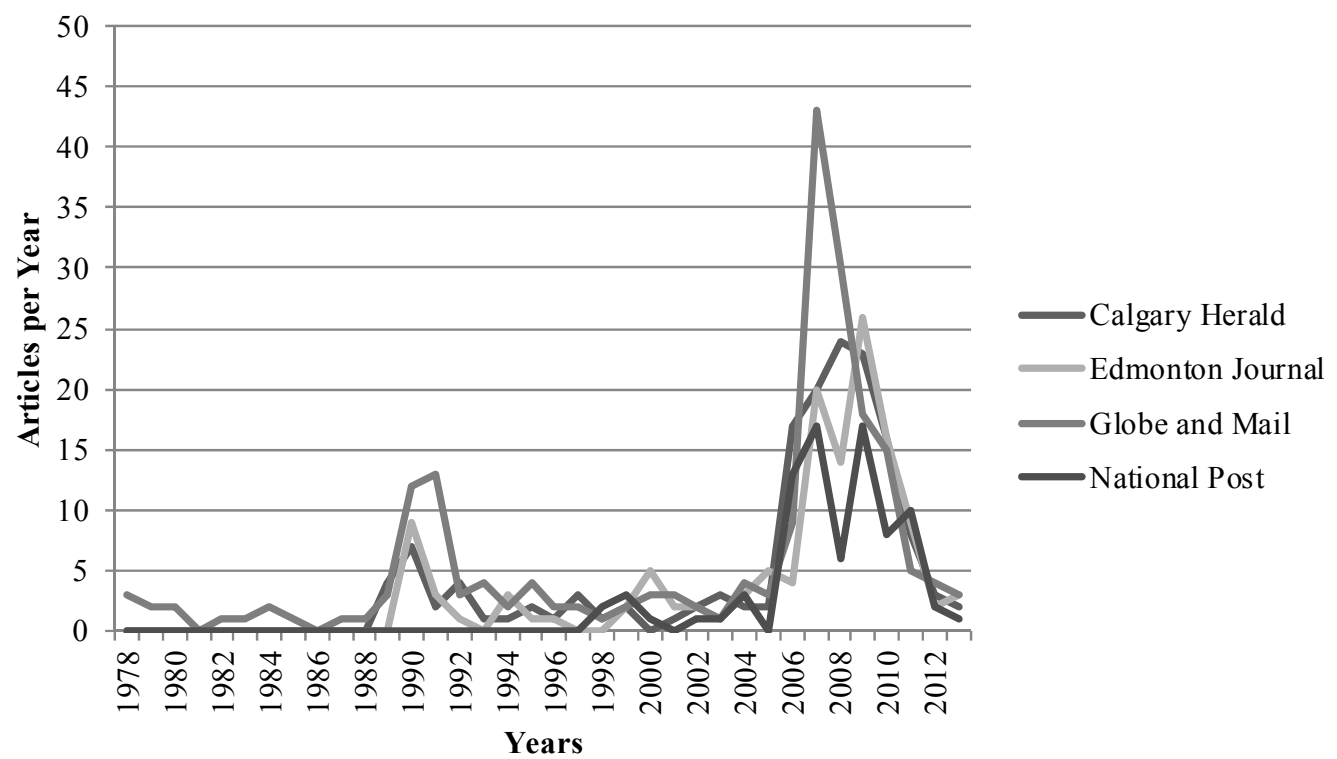

Figure 1. Salience of the applicable articles in the four newspapers

As shown in Figure 1, all four newspapers show a remarkable overlap as to when greening as it relates to energy issues was a hot topic with one peak between 1989 and 1992 and another around 2006-2009. The results also indicate that greening as it relates to energy issues is seen as an issue of decreasing importance in recent years. The first peak could have been due to the public visibility of discourses leading up to the 1992 UN Conference on the Environment and Development which resulted in the Framework Convention on Climate Change. However, the term UN Conference on the Environment and Development did not show up once in the newspaper articles. As to the second peak between 2006-2009, this peak is mimicked by a peak in the mentioning of the Kyoto protocol (Globe and Mail: $2006(n=2), 2007(n=10), 2008(n=3), 2009(n=1)$; National Post: $2006(n=3), 2007(n=4), 2008(n=0), 2009(n=0)$; Calgary Herald: $2006(n=1), 2007(n=3), 2008(n=1)$, $2009(n=1)$; Edmonton Journal: $2006(n=1), 2007(n=3), 2008(n=1), 2009(n=1))$. The term Rio which could be linked to the Earth Summit from 1992 and Rio+20 from 2012 did not show a correlation to the greening peaks with for example the National Post not mentioning the term at all in the greening and energy articles and the other sources only having 6 articles that mention the term Rio. This suggests that there might be a disconnect at least in the newspapers between the Rio discourse and the greening discourses. Indeed the Rio +20 outcome document "The future we want" did not mention the term greening once either (United Nations Conference on Sustainable Development (Rio+20), 2012) suggesting that the disconnect goes beyond media coverage.

\subsection{Issue of Scope}

The issue of scope is another area of importance for the greening discourse. What is covered influences to a certain extent policies and actions.

\subsubsection{Scope of Energy Sources Covered}


Table 1. Frequency of mentioning of different energy sources in the greening articles

\begin{tabular}{|c|c|c|c|c|c|c|c|c|c|c|c|c|c|c|c|}
\hline \multirow[t]{2}{*}{$\begin{array}{l}\text { Energy } \\
\text { Source Code }\end{array}$} & \multicolumn{3}{|c|}{ National Post $\mathrm{n}=78=100 \%$} & \multirow[t]{2}{*}{$\begin{array}{l}\text { Energy } \\
\text { Source Code }\end{array}$} & \multicolumn{3}{|c|}{ Globe and Mail $\mathrm{n}=194=100 \%$} & \multirow[t]{2}{*}{$\begin{array}{l}\text { Energy } \\
\text { Source Code }\end{array}$} & \multicolumn{3}{|c|}{$\begin{array}{l}\text { Calgary Herald } \\
\mathrm{n}=142=100 \%\end{array}$} & \multirow[t]{2}{*}{$\begin{array}{l}\text { Energy } \\
\text { Source Code }\end{array}$} & \multicolumn{3}{|c|}{$\begin{array}{l}\text { Edmonton Journal } \\
\mathrm{n}=124=100 \%\end{array}$} \\
\hline & $\begin{array}{l}\text { Total } \\
\text { hitcounts } \\
(\mathrm{n}=)\end{array}$ & $\begin{array}{l}\text { Article } \\
\text { count } \\
(\mathrm{n}=)\end{array}$ & $\begin{array}{l}\text { Atticle } \\
\text { ccunt } \\
(\%)\end{array}$ & & $\begin{array}{l}\text { Total } \\
\text { hitcounts } \\
(\mathbf{n}=)\end{array}$ & $\begin{array}{l}\text { Article } \\
\text { count } \\
(\mathrm{n}=)\end{array}$ & $\begin{array}{l}\text { Article } \\
\text { count } \\
\text { (\%) }\end{array}$ & & $\begin{array}{l}\text { Total } \\
\text { hitcounts } \\
(\mathrm{n}=)\end{array}$ & $\begin{array}{l}\text { Article } \\
\text { count } \\
(\mathrm{n}=)\end{array}$ & $\begin{array}{l}\text { Article } \\
\text { count } \\
\text { (\%) }\end{array}$ & & $\begin{array}{l}\text { Total } \\
\text { hitcounts } \\
\text { (n=) }\end{array}$ & $\begin{array}{l}\text { Article } \\
\text { count } \\
(\mathrm{n}=)\end{array}$ & $\begin{array}{l}\text { Article } \\
\text { count } \\
(\%)\end{array}$ \\
\hline Energy & 457 & 78 & 100 & Energy & 781 & 194 & 100 & Energy & 567 & 142 & 100 & Energy & 545 & 124 & 100 \\
\hline Gas & 122 & 36 & 46.2 & Gas & 273 & 74 & 38.1 & Gas & 235 & 80 & 56.3 & Gas & 183 & 51 & 41.1 \\
\hline Solar Power & 66 & 26 & 33.3 & Oil & 150 & 60 & 30.9 & Oil & 110 & 33 & 23.2 & Oil & 104 & 45 & 36.3 \\
\hline Electricity & 68 & 21 & 26.9 & Solar Power & 117 & 53 & 27.3 & Solar Power & 79 & 32 & 22.5 & Electricity & 75 & 25 & 20.2 \\
\hline Oil & 59 & 19 & 24.4 & Electricity & 114 & 46 & 23.7 & Electricity & 77 & 31 & 21.8 & Solar Power & 73 & 25 & 20.2 \\
\hline Wind Power & 26 & 14 & 17.9 & Wind Power & 154 & 46 & 23.7 & $\begin{array}{l}\text { Oil sand and } \\
\text { Oilsand }\end{array}$ & 86 & 28 & 19.7 & $\begin{array}{l}\text { Oil sand and } \\
\text { Oilsand }\end{array}$ & 137 & 24 & 19.4 \\
\hline Coal & 28 & 13 & 16.7 & Coal & 114 & 42 & 21.6 & Wind Power & 94 & 28 & 19.7 & Coal & 73 & 22 & 17.7 \\
\hline $\begin{array}{l}\text { Renewable } \\
\text { Energy }\end{array}$ & 20 & 12 & 15.3 & Hydro & 64 & 30 & 15.5 & Coal & 45 & 27 & 19 & $\begin{array}{l}\text { Renewable } \\
\text { Energy }\end{array}$ & 39 & 21 & 16.9 \\
\hline Fossil & 17 & 9 & 11.5 & Fossil & 39 & 22 & 11.3 & $\begin{array}{l}\text { Renewable } \\
\text { Energy }\end{array}$ & 35 & 14 & 9.8 & Wind Power & 53 & 21 & 16.9 \\
\hline Green energy & 12 & 9 & 11.5 & $\begin{array}{l}\text { Renewable } \\
\text { Energy }\end{array}$ & 35 & 21 & 10.8 & Hydro & 21 & 12 & 8.5 & $\begin{array}{l}\text { Alternative } \\
\text { Energy }\end{array}$ & 28 & 16 & 12.9 \\
\hline Hydro & 35 & 9 & 11.5 & Nuclear & 79 & 16 & 8.2 & Fossil & 18 & 11 & 7.7 & Fossil & 19 & 13 & 10.5 \\
\hline $\begin{array}{l}\text { Alternative } \\
\text { Energy }\end{array}$ & 12 & 8 & 10.3 & $\begin{array}{l}\text { Alternative } \\
\text { Energy }\end{array}$ & 26 & 15 & 7.7 & $\begin{array}{l}\text { Alternative } \\
\text { Energy }\end{array}$ & 12 & 9 & 6.3 & Green energy & 10 & 8 & 6.5 \\
\hline Nuclear & 72 & 7 & 9 & Geothermal & 28 & 13 & 6.7 & Biodiesel & 14 & 7 & 4.9 & Nuclear & 16 & 8 & 6.5 \\
\hline $\begin{array}{l}\text { Oil sand and } \\
\text { Oilsand }\end{array}$ & 26 & 7 & 9 & Biomass & 17 & 10 & 5.2 & Biofuel & 14 & 6 & 4.2 & Biodiesel & 17 & 8 & 6.4 \\
\hline Biodiesel & 5 & 5 & 6.4 & $\begin{array}{l}\text { Oil sand and } \\
\text { Oilsand }\end{array}$ & 51 & 9 & 4.6 & Nuclear & 40 & 6 & 4.2 & Biofuel & 21 & 7 & 5.6 \\
\hline Biofuel & 9 & 5 & 6.4 & Green energy & 8 & 6 & 3.1 & Green energy & 4 & 4 & 2.8 & Hydro & 10 & 7 & 5.6 \\
\hline Geothermal & 7 & 5 & 6.4 & Hydrocarbon & 6 & 6 & 3.1 & Geothermal & 8 & 3 & 2.1 & Biomass & 11 & 4 & 3.2 \\
\hline Clean coal & 3 & 3 & 3.8 & Biofuel & 7 & 5 & 2.6 & Hydrocarbon & 3 & 3 & 2.1 & Hydrocarbon & 4 & 4 & 3.2 \\
\hline Biogas & 0 & 0 & 0 & Biodiesel & 7 & 4 & 2.5 & Biomass & 3 & 2 & 1.4 & Clean coal & 2 & 2 & 1.6 \\
\hline Biomass & 0 & 0 & 0 & Biogas & 6 & 3 & 1.5 & Clean coal & 2 & 2 & 1.4 & Biogas & 15 & 1 & 0.8 \\
\hline Hydrocarbon & 0 & 0 & 0 & Clean coal & 0 & 0 & 0 & Biogas & 0 & 0 & 0 & Geothermal & 1 & 1 & 0.8 \\
\hline
\end{tabular}

Table 1 reveals a few issues. Three of the four newspapers mentioned oil and gas the most, which might not be surprising for the two Alberta newspapers. However the Globe and Mail followed the same pattern and the National Post was not far behind making oil the $3^{\text {rd }}$ most mentioned source. If we look at the term oilsand, Alberta newspapers used this term much more often than the National newspapers. This is not surprising given that Alberta is the place where oilsands are a source of extraction of hydrocarbon energy. Coal was mentioned in more than $10 \%$ of the articles in each source; however, the term clean coal which one could see as a term indicating greening effort related to coal was only mentioned in $2-3 \%$ of the articles in all sources. Various new forms of energy linked to renewable and greener such as biodiesel, biogas, biomass, were not very visible in all newspapers; neither was nuclear energy which is also put forward by some as green energy. The very term green energy was mentioned between $11.5 \%$ in the National Post and $2.8 \%$ in the Calgary Herald, with the Globe and Mail being at 3.1\% and the Edmonton Journal at $6.5 \%$.

Besides the higher visibility for the term oilsand in the Alberta versus National newspapers no real difference in visibility was evident in the newspapers whether based on geography, reach or ownership. Using the term green energy we obtained 32400 hits in Google Scholar and around 21 million in Google. Only 27 articles in our sources used the term; of the three articles that had the term in the title, one in the Edmonton Journal stated, "Alberta can switch its electricity source from coal to clean renewable energy sources in 20 years, creating jobs, reducing greenhouse gas and creating a more stable price for energy, says a new Pembina Institute report to be released today" (Brooymans, 2009); another stated in 2007 that biofuel has a hard road ahead (Young, 2007) and a 2011 article in the National Post put forward the claim that the increase in influence of green movements might diminish and wrote about the high cost and other problematic issues of green energy (Jonas, 2011). 


\subsubsection{Scope of Green}

Another aspect of scope is what is covered under various terms of green.

Table 2. Frequency of different 'green' containing terms and the term sustainability in 'Greening' articles

\begin{tabular}{|c|c|c|c|c|c|c|c|c|c|c|c|c|c|c|c|}
\hline \multirow[t]{2}{*}{ Code } & \multicolumn{3}{|c|}{ National Post $\mathrm{n}=78=100 \%$} & \multirow[t]{2}{*}{$\begin{array}{l}\text { Energy } \\
\text { Source Code }\end{array}$} & \multicolumn{3}{|c|}{ Globe and Mail $\mathrm{n}=194=100 \%$} & \multirow[t]{2}{*}{$\begin{array}{l}\text { Energy } \\
\text { Source Code }\end{array}$} & \multicolumn{3}{|c|}{$\begin{array}{l}\text { Calgary Herald } \\
n=142=100 \%\end{array}$} & \multirow[t]{2}{*}{$\begin{array}{l}\text { Energy } \\
\text { Source Code }\end{array}$} & \multicolumn{3}{|c|}{$\begin{array}{l}\text { Edmonton Journal } \\
\mathrm{n}=124=100 \%\end{array}$} \\
\hline & $\begin{array}{l}\text { Total } \\
\text { hitcounts } \\
(\mathbf{n}=)\end{array}$ & $\begin{array}{l}\text { Article } \\
\text { count } \\
(\mathrm{n}=)\end{array}$ & $\begin{array}{l}\text { Article } \\
\text { count } \\
(\%)\end{array}$ & & $\begin{array}{l}\text { Total } \\
\text { hitcounts } \\
(\mathrm{n}=)\end{array}$ & $\begin{array}{l}\text { Article } \\
\text { count } \\
(\mathrm{n}=)\end{array}$ & $\begin{array}{l}\text { Article } \\
\text { count } \\
(\%)\end{array}$ & & $\begin{array}{l}\text { Total } \\
\text { hitcounts } \\
(\mathrm{n}=)\end{array}$ & $\begin{array}{l}\text { Article } \\
\text { count } \\
(\mathrm{n}=)\end{array}$ & $\begin{array}{l}\text { Article } \\
\text { count } \\
(\%)\end{array}$ & & $\begin{array}{l}\text { Total } \\
\text { hitcounts } \\
(\mathrm{n}=)\end{array}$ & $\begin{array}{l}\text { Article } \\
\text { count } \\
(\mathrm{n}=)\end{array}$ & $\begin{array}{l}\text { Article } \\
\text { count } \\
(\%)\end{array}$ \\
\hline Green & 322 & 78 & 100 & Green & 814 & 194 & 100 & Green & 566 & 142 & 100 & Green & 436 & 124 & 100 \\
\hline Greenhouse & 154 & 29 & 37.1 & Greening of & 121 & 105 & 54.1 & Greening of & 61 & 53 & 37.3 & Greenhouse & 103 & 40 & 32.2 \\
\hline Greening of & 42 & 27 & 34.6 & Greenhouse & 145 & 43 & 22.1 & Greenhouse & 154 & 50 & 35.2 & Greening of & 45 & 33 & 26.6 \\
\hline Sustainability & 41 & 18 & 23.1 & Sustainability & 65 & 34 & 17.5 & Greener & 41 & 24 & 16.9 & Greener & 30 & 20 & 16.1 \\
\hline Greener & 21 & 11 & 14.1 & Greener & 35 & 25 & 12.8 & Sustainability & 46 & 15 & 10.6 & Sustainability & 29 & 10 & 8.1 \\
\hline Go green & 4 & 4 & 5.1 & Go green & 20 & 13 & 6.7 & Go green & 15 & 8 & 5.6 & Go green & 15 & 9 & 7.3 \\
\hline Greenwash & 2 & 2 & 2.6 & Greened & 6 & 5 & 2.4 & Greenwash & 2 & 2 & 1.4 & Greenwash & 3 & 3 & 2.4 \\
\hline Greened & 1 & 1 & 1.3 & Greenwash & 5 & 4 & 2 & Greened & 1 & 1 & 0.7 & Greened & 0 & 0 & 0 \\
\hline
\end{tabular}

Table 2 reveals various issues.

\subsubsection{Greenwashing}

One issue revealed in Table 2 is that the term greenwash ranked second last and last, with only 11 articles covering the topic. One article defined greenwashing as follows, "Greenwashing refers to the practice of appropriating an eco-friendly posture for marketing purposes rather than to further sustainability" (Shaw, 2008); another stated: "Companies have become so adept at making themselves and their products look more environmentally friendly than they really are, the practice has its own name: greenwashing" (Scott, 2008). One article discussed a study done by TerraChoice Environmental Marketing, which found that "99.9 per cent of so--called green products make false, misleading or unsubstantiated claims" (Scott, 2008). As to what is discussed in the 11 articles various issues were seen to arise on the public side of greenwashing. Firstly, many consumers were seen as not being aware of the meaning of "green" and what makes a product green. One article highlighted various results of a 2007 Ipsos Reid study namely that, " $64 \%$ of Canadians 'strongly' or 'somewhat' agreed that when companies call a product 'green', it is usually just a marketing tactic" (Shaw, 2008) that "39\% of those surveyed said they preferred to buy products they believe to be "environmentally friendly", almost half (48\%) wrongly assumed that products marketed as green have a beneficial impact on the environment. Only $22 \%$ realized that so-called green products tend to have less of a negative environmental impact than previous generations of the item or competing products" (Shaw, 2008). The article gave voice to the sentient that "the gap creates significant risk of embarrassment for companies and disillusionment for consumers" (Shaw, 2008). Secondly, many "green" alternatives are not really sustainable; for example, one article discusses the use of coconut oil to fly a plane (Marotte, 2008). Another major problem espoused in the articles is the ability of marketers to play on the naivety of consumers on the nitty-gritty details. One article stated, "Take the recycling symbol on juice bottles and paper products that has a dark 'mobius loop' on a light background. What does it mean? If you guessed recycled content, you're wrong. You're also not alone". Marketers have figured out that most consumers do not know the difference between a product that is recyclable and a product made of recycled content, says Case (Scott, 2008). "A light symbol on a dark background means the product contains recycled material" (Scott, 2008). The articles portray greenwashing as a gimmick to keep the US as a consumer (Cryderman, 2009a). People want to eat natural foods, says [Stephen Gardner, director of litigation for the U.S. Centre for Science in the Public Interest]. "The corporations know it and they slap the natural label on products. They know damn well it isn't'” (Scott, 2008).

Throughout the articles there is a demand for a universal standard which all companies can adhere to and which provide clear standards for the public. This transparency is seen as necessary in order to create a barrier to greenwashing. Several articles discuss corporations and guidelines which are already in place, such as "the GRI [Global Reporting Initiative], launched in 1997. It is made up of thousands of experts, in dozens of countries worldwide, who take part in working groups and governance bodies to develop a detailed set of guidelines to measure and disclose corporate behaviour. The guidelines cover economic, environmental, social, human rights, labour practices, product responsibility (with increasing focus on supply chains) and governance. The GRI offers specific areas to examine, and is exhaustive in categories on which to report-everything from transport of hazardous materials to donations to political parties" (McLaren, 2008). 
One article espouses the idea that it is the responsibility of the government to guide this idea. The author comments: "The question, then, is what are we going to do about it? By 'we', I of course mean the provincial government, which represents all Albertans" (Frank, 2008).

Examples of greenwashing were also linked to major oil companies. One article referred to the actions of BP Amoco, which implemented "solar panels on the roofs of some of its gas stations, to help you put 'some sun in your life", and Shell, which "touts its 'commitment to the development of renewables' such as solar, biomass and forestry", yet both companies "spend less than $1 \%$ of their budget on renewable energy" (Bruno \& Karliner, 2000). Barack Obama "has pledged to break his country's addiction to 'dirty', dwindling and dangerously expensive oil during his presidency" (Cryderman, 2008b), creating a need for Alberta oil marketers to take action. Greenwashing is seen as a gimmick to keep the United States and Europe as consumers (Cryderman, 2008b, 2009a). Greenwashing was also seen to occur because companies do not want to be seen as negative: "In general, companies, including Alberta oil companies, and government agencies, including Alberta agencies, have trouble saying things that everybody knows to be true and that are embarrassing, or reflect badly on them,' Peter Sandman, a communications guru, said in an interview with the Calgary Herald (Cryderman, 2008a)".

\subsubsection{Greening of}

Investigating the phrase "Greening of" allowed us to look into what is seen in need of being greened. The term "greening of" could be found in $\mathrm{n}=219$ articles. In terms of what needs to be greened, amongst all the articles searched, there was a wide range of topics covered, from dairy cows to cars to churches. The articles discussed, among others, the 'greening of' corporations and businesses $(n=35)$; government $(n=14)$, various countries (such as Canada $n=4$, USA $n=4$, Europe $n=3$, China $n=3$ and Spain $n=1)$; other places $(n=43)$, automobiles $(n=12)$ and building and infrastructure $(n=25)$. Greening of the environment was mentioned $(n=13)$. In terms of energy, we found the term greening of energy $(n=3)$; as to the greening of individual energy sources we found coal $(n=1)$, nuclear energy $(n=1)$, energy supply mix $(n=2)$, gasoline $(n=3)$, electricity sector $(n=6)$ and oil $(n=10)$ mentioned. As to the sentiment of oil, the articles were focusing on the oilsand with $(\mathrm{n}=5)$ saying it is under way, has to be done and has to increase, whereas $(n=4)$ were about the futility of greening oil. One article quoted Alberta Environment Minister Rob Renner talking about how "New low-carbon fuel standards proposed in the Northeastern U.S. could actually slow the greening of the oilsands (McLean, 2010). Another article talked about the problem with Premier Harper's pledge that "his government would ban exports of raw bitumen to any country that failed to conform with Canadian carbon emission reduction standards, including the U.S" (Simons, 2008). Another article from the comment section in 2010 stated, "The greening of fossil-fuel production and the development of renewable and alternative energy should occur at the same time, using biodiversity and the health of our ecology as guiding principles. Why must we have sustainable and responsible development of the oil sands? If we don't do it well, others will come in and do it badly" (Das, 2010).

According to the attitudes displayed throughout the newspapers, the greening of oil extraction and the use of natural gas is a good thing. The topics were mostly covered together. The majority of the articles which were written on oil and gas were found in the Edmonton Journal and the Calgary Herald. In the Edmonton Journal and the Calgary Herald, the general opinion--which included the public, the owners of Exxon Mobil, and the governments in the US and Canada--showed a desire to green the oilsands. One article in the Edmonton Journal interviews several of the Rockefellers, owners of Exxon Mobil. "Descendants of John D. Rockefeller want the company he founded, Exxon Mobil Corp., to spend more money on alternatives to crude oil and cut greenhouse gas emissions from its refineries and fuels" (Anonymous, 2008). An article in the Calgary Herald discussed the international agreement between Canada and the US to green oil sands: "Energy industry officials welcomed a joint pledge Thursday by Canadian and U. S. leaders to work together on clean energy technology amid calls to cut Alberta's "dirty oil" exports" (Schmidt, 2009). Within the National Post and the Globe and Mail, there was a positive portrayal of greening the use of oil, akin to the Edmonton Journal and the Calgary Herald. One article in the National Post for example interviewed Mr. Pereira Almao, a former employee at Petroleos de Venezuela SA, who has worked to developed greener oil extraction processes and which revealed the opinion that greening the oilsands is a positive practice.

Outside of oil, one article from 1997 in the Globe and Mail highlighted the attempt of Statistics Canada to quantify the value of the environment to the Canadian economy and the problem with the approach (Strauss, 1997). Another article highlighted that "greening of society" will be diminished by the NIMBY syndrome - not in my backyard and cost benefit analysis (Raymond, 1990b). We also found the following phrase mentioned one time: greening of policy agenda, public sector policy, protectionism, Canadian attitude, public attitude, electorate, Canadian Politics and US Canadian Relationship. Greening of public consciousness was mentioned twice. Greening of the Liberal Party of Canada was mentioned once and of the Conservative Party was mentioned twice. 
Greening of various politicians was mentioned. Finally we also found that greening of Religion was mentioned twice. In the discussion of the greening of vehicles, hybrids are often discussed as the best option: "the greening of the automobile is going to be left to the hybrid" (Fletcher, 2002). In regards to the greening of business and corporations, responsibility for all practices is expected of the corporate world. As well, the results of greening are anticipated to be positive and significant: "Greening of industry and public awareness of climate change and other environmental issues are key drivers of renewable energy and energy efficiency, the report said" (Anonymous, 2007). As to discussion about the greening of homes and development, for example in the Edmonton Journal, there is an article which discusses how roofs can be greened: "Speaking of the greening of buildings, Penn State University researchers are developing a system to replace the tar-and-gravel materials used on flat roofs with living plants" (Edmonton Journal, 2000).

\subsection{Issue of Voices}

It is well known that journalists influence media delivery and often set the agendas and that journalists are influenced by their environment (Allport \& Faden, 1940; Bulkow, Urban, \& Schweiger, 2013; Carragee \& Roefs, 2004; Illia, Lurati, \& Casalaz, 2013; McCauley, Blake, Meissner, \& Viswanath, 2013; Reese, 2001; Shoemaker, Vos, \& Reese, 2008; Sill, Metzgar, \& Rouse, 2013; Tilley \& Hollings, 2008; Weaver \& Elliott, 1985). When we auto-coded for credits to news services, we found that very few of the articles credited international news services such as Associated Press $(n=14)$. A national news service (Canadian Press $(n=10)$ ) was also credited. However the majority of articles had local content and many of the articles did contain original material that did not originated from a news service although like in the case of the three newspapers owned by PostMedia Network INC (Edmonton Journal, Calgary Herald and National Post), various articles by the same journalist were occasionally shared between the three newspapers. Beyond the journalist, who is given a voice within media coverage is seen as essential by many.

Table 3. People and Places frequency in 'Greening' articles

\begin{tabular}{|c|c|c|c|c|c|c|c|c|c|c|c|c|c|c|c|}
\hline \multirow[t]{2}{*}{ Code } & \multicolumn{3}{|c|}{ National Post $\mathrm{n}=78=10) \%$} & \multirow[t]{2}{*}{$\begin{array}{l}\text { Energy Source } \\
\text { Code }\end{array}$} & \multicolumn{3}{|c|}{ Globe and Mail $n=194=100 \%$} & \multirow[t]{2}{*}{$\begin{array}{l}\text { Energy Source } \\
\text { Code }\end{array}$} & \multicolumn{3}{|c|}{$\begin{array}{l}\text { Calgary Herald } \\
\mathrm{n}=142=100 \%\end{array}$} & \multirow[t]{2}{*}{$\begin{array}{l}\text { Energy } \\
\text { Code }\end{array}$} & \multicolumn{3}{|c|}{$\begin{array}{l}\text { Edmonton Journal } \\
\mathrm{n}=124=100 \%\end{array}$} \\
\hline & $\begin{array}{l}\text { Total } \\
\text { hitcount } \\
\mathrm{s} \\
(\mathrm{n}=)\end{array}$ & $\begin{array}{l}\text { Articl } \\
\mathrm{e} \\
\text { count } \\
(\mathrm{n}=)\end{array}$ & $\begin{array}{l}\text { Articl } \\
\mathrm{e} \\
\text { count } \\
(\%)\end{array}$ & & $\begin{array}{l}\text { Total } \\
\text { hitcount } \\
s \\
(n=)\end{array}$ & $\begin{array}{l}\text { Articl } \\
\text { count } \\
(\mathrm{n}=)\end{array}$ & $\begin{array}{l}\text { Articl } \\
\mathrm{e} \\
\text { count } \\
(\%)\end{array}$ & & $\begin{array}{l}\text { Total } \\
\text { hitcount } \\
\mathrm{s} \\
(\mathrm{n}=)\end{array}$ & $\begin{array}{l}\text { Articl } \\
\mathrm{e} \\
\text { count } \\
(\mathrm{n}=)\end{array}$ & $\begin{array}{l}\text { Articl } \\
\mathrm{e} \\
\text { count } \\
(\%)\end{array}$ & & $\begin{array}{l}\text { Total } \\
\text { hitcount } \\
\mathrm{s} \\
(\mathrm{n}=)\end{array}$ & $\begin{array}{l}\text { Articl } \\
\mathrm{e} \\
\text { count } \\
(\mathrm{n}=)\end{array}$ & $\begin{array}{l}\text { Articl } \\
\mathrm{e} \\
\text { count } \\
\text { (\%) }\end{array}$ \\
\hline Business & 222 & 78 & 100 & Canada & 922 & 194 & 100 & Canada & 594 & 141 & 99.3 & Business & 308 & 124 & 100 \\
\hline Canada & 339 & 78 & 100 & Government & 344 & 114 & 58.8 & Business & 233 & 72 & 50.7 & Canada & 308 & 124 & 100 \\
\hline Government & 134 & 44 & 56.4 & Business & 335 & 102 & 52.6 & Indust* & 202 & 72 & 50.7 & Indust* & 236 & 80 & 64.5 \\
\hline Indust ${ }^{*}$ & 143 & 41 & 52.6 & Indust* & 350 & 91 & 46.9 & Alberta & 445 & 70 & 49.3 & Alberta & 374 & 55 & 44.4 \\
\hline Earth & 37 & 25 & 32 & United States & 67 & 60 & 30.9 & Government & 268 & 62 & 43.7 & Government & 243 & 44 & 35.5 \\
\hline America & 33 & 23 & 29.5 & America & 84 & 59 & 30.4 & Earth & 107 & 35 & 24.6 & Corporat* & 53 & 26 & 21 \\
\hline Corporat* & 52 & 21 & 26.9 & Canadians & 100 & 46 & 23.7 & Park(s) & 84 & 35 & 24.6 & Earth & 76 & 24 & 19.3 \\
\hline Consumer & 51 & 19 & 24.4 & Park(s) & 110 & 45 & 23.1 & Consumer & 73 & 34 & 23.9 & Park(s) & 43 & 24 & 19.3 \\
\hline Expert & 24 & 19 & 24.3 & Consumer & 176 & 43 & 22.2 & Corporat* & 52 & 33 & 23.2 & America & 48 & 23 & 18.5 \\
\hline Park(s) & 27 & 17 & 21.8 & Earth & 72 & 42 & 21.6 & Expert & 35 & 26 & 18.3 & Environmentalis: & 44 & 22 & 17.7 \\
\hline Alberta & 51 & 16 & 20.5 & The Public & 41 & 40 & 20.6 & Canadians & 45 & 22 & 15.5 & Expert & 39 & 20 & 16.1 \\
\hline Canadians & 37 & 16 & 20.5 & Environmentalist & 60 & 35 & 18 & Nature & 27 & 21 & 14.7 & Nature & 31 & 18 & 14.5 \\
\hline The Public & 25 & 15 & 19.2 & Corporat" & 114 & 33 & 17 & Environmentalist & 33 & 18 & 12.7 & Consumer & 45 & 17 & 13.7 \\
\hline United States & 30 & 15 & 19.2 & Alberta & 121 & 31 & 16 & United States & 26 & 17 & 12 & United States & 24 & 16 & 12.9 \\
\hline China & 44 & 10 & 12.8 & Nature & 53 & 31 & 15.9 & America & 30 & 16 & 11.3 & Canadians & 17 & 11 & 8.9 \\
\hline Society & 11 & 9 & 1.5 & Expert & 47 & 30 & 15.4 & The Public & 28 & 14 & 9.9 & China & 101 & 11 & 8.9 \\
\hline Environmentalist & 23 & 8 & 10.3 & Society & 40 & 28 & 14.64 & Farmer & 44 & 13 & 9 & Society & 21 & 11 & 8.8 \\
\hline Nature & 10 & 8 & 10.2 & China & 66 & 26 & 13.4 & Society & 36 & 12 & 8.4 & Americans & 20 & 9 & 7.3 \\
\hline Wildlife & 12 & 7 & 89 & Farmer & 45 & 13 & 6.7 & Wildlife & 17 & 12 & 8.4 & The Public & 12 & 8 & 6.5 \\
\hline Farmer & 7 & 5 & 6.4 & Wildlife & 19 & 12 & 6.1 & China & 22 & 10 & 7 & Wildlife & 16 & 7 & 5.6 \\
\hline Americans & 3 & 3 & 3.8 & Americans & 18 & 10 & .2 & $\begin{array}{l}\text { Aboriginal } \\
\text { People/First } \\
\text { Nation/Indigenou } \\
\text { s People }\end{array}$ & 12 & 7 & 4.9 & Farmer & 13 & 6 & 4.8 \\
\hline $\begin{array}{l}\text { Aboriginal } \\
\text { People/First } \\
\text { Nation/Indigenou } \\
\text { s People }\end{array}$ & 0 & 0 & 0 & $\begin{array}{l}\text { Aboriginal } \\
\text { People/First } \\
\text { Nation/Indigenou } \\
\text { s People }\end{array}$ & 6 & 3 & .5 & Americans & 5 & 5 & 3.5 & $\begin{array}{l}\text { Aboriginal } \\
\text { People/First } \\
\text { Nation/Indigenou } \\
\text { s People }\end{array}$ & 23 & 5 & 4 \\
\hline Inuvik & 0 & 0 & 0 & Inuvik & 1 & 1 & .5 & Inuvik & 18 & 1 & 0.7 & Inuvik & 26 & 1 & 0.8 \\
\hline Inuit & 0 & 0 & 0 & Inuit & 0 & 0 & & Inuit & 2 & 1 & 0.7 & Inuit & 0 & 0 & 0 \\
\hline
\end{tabular}

Table 3 reveals an obvious hierarchy of who was given a voice in the greening coverage. As to the geographical focus of the voices, every article had a national focus. At the same time many articles covered the relationship of Canada with other countries such as the USA and the issues related to greening in other countries such as China, various European countries and Japan. No article seemed to have had a solely local focus even the ones that told 
personal stories of people. As to actors mentioned, businesses were mentioned the most, with government being the next group. On the other end of visibility the least mentioned were people in Inuvik, Inuit's and Aboriginal/First Nation/Indigenous people. Even with their low visibility in general, it is still newsworthy that the National Post did not mention them even once. Other groups such as farmers were mentioned more or less the same between the newspapers independent of the local or national focus. Between 23-25\% of the articles in all newspapers used the term consumer. As to who was meant with the term expert, the geographical breadth of experts sought was often global (Fekete \& D'Aliesio, 2008) and federal. Experts in climate change $(\mathrm{n}=8)$, water issues $(n=5)$, energy $(n=4)$, environmental sustainability $(n=4)$, green buildings, ecotourism $(n=3)$, energy consumption $(n=2)$, real estate $(n=2)$, local experts $(n=2)$, energy policy $(n=2)$, wind energy $(n=2)$ and chemistry $(\mathrm{n}=2)$ were mentioned. Experts in the following topics were mentioned once: renewable-energy technologies, parasites, nature, environmental health, sustainable design, pipeline construction, oilsands knowledge-generation, forestry, art, anthropology, culture, planners, green marketing, landscape architects, energy efficiency, engineer, land reclamation, biogas, green economy, geology, petroleum engineering, environmental policy, nuclear, agricultural, industry, and NGO. One article mentioned experts in a negative way such as spin doctoring (Martin, 2007).

One article mentioned a survey of many 'experts', "More than three out of four leading Canadian bureaucrats, scientists and industry leaders believe the Harper government is missing the boat on 'greening' the economy and adopting the wrong policies to address climate change, according to a new international study. The survey of 5,109 senior stakeholders from government, industry and academia was conducted by McAllister Opinion Research and is one of the largest studies of its kind to assess the opinions of leading government and professional experts. Out of 4,282 Canadian experts who participated in the survey, which also included U.S. and European experts, 77 per cent rated Canada's efforts at addressing climate change as poor or very poor, while 75 per cent had the same opinion about the country's performance in developing a green economy" (de Souza, 2010).

In general, the discussion in the Globe and Mail was a presentation of the perspectives of individual citizens, small businesses, and corporate representatives on the government's involvement in greening, and the need to increase government action in greening practices. One article, Greening of the oilsands, incorporated a variety of perspectives on greening and the government: David Ebner interviewed Robert Mansell (head of the University of Calgary's institute for sustainable energy, environment and economy), Marcel Coutu (chief executive officer of the largest owner of Syncrude Canada Ltd., Canadian Oil Sands Trust), Clive Mather (CEO of Shell Canada Ltd.), Drew Zieglgansberger (supervisor of oil sands drilling at EnCana), and Eric Lloyd (president of Petroleum Technology Alliance Canada), who all agreed that change was necessary in order to become sustainable and that the government was failing to act accordingly. "If governments aren't going to lead, it won't happen" says Robert Mansell (Ebner, 2007). In another article, Michael Rose, CEO of Duvernay Oil Corp. in Calgary, states that "we should be doing everything we can to reduce air and water pollution" (Blackwell, 2007).

The opinions being presented in the National Post were those of experts in the field of environmental sciences and business owners who were taking the initiative to go green. In an article discussing the greening of the oil sands and the energy industry in general, Juergen Gailer, a university professor at the University of Calgary who teaches environmental sciences stated that "The average person has not been so much informed about what's going on [until now], so environmental science has huge job opportunities for students". Other articles went into detail about the oil sands, and discussed the new 'green field'; "Canadian businesses are in for a greening, and one of the industries leading the growth of environmental technologies is found in the burgeoning northern Alberta oilsands projects" (Sankey, 2007). The same article interviewed Grant Trump, president of the Environmental Careers Organization based in Calgary who stated that "There is a golden opportunity for young people these days to pursue careers in environmental studies because there's not going to be any shortage of work in the future". Furthermore, he states that "The oil and gas industry holds a very promising career" (Sankey, 2007).

Many of the articles were interviews with citizens of Edmonton who were trying to green their own lives. From automobile manufacturers to roadies working for the Vans Warped Tour, the Edmonton Journal focused on current greening actions. One article discussed the actions being taken by various churches and religious congregations, and offered their perspective on greening: "The Earth is not a hotel. It's our home". The article contained an interview with a pastor from a church in British Columbia who had recently finished greening the church's building (Todd, 2008). The positive stories and encouraging messages regarding greening in the Edmonton Journal were also found in the other regional newspaper, the Calgary Herald. The Calgary Herald offered a variety of articles which discussed current actions being taken to go green, including the best brands 
and companies to use when making green choices. One article discussed the greening of ski resorts, which generally tend to have detrimental effects on the environment. "Canadian resorts are taking up the challenge" and changing their actions, according to Dayle Parker, who interviewed ski resort owners all over Canada who have been making a conscious effort to be more sustainable (Parker, 2006).

\subsection{Issue of Solutions}

\subsubsection{The Role of Government}

The Globe and Mail discussed greening as a necessary action which requires government attention. The articles contained a critical focus on the national government, and the opinions of a multitude of corporations, businesses, and individuals on the government. The articles contained very little discussion on greening as such but instead focused on government leadership which was portrayed as necessary in order to become sustainable. In the Globe and Mail, the article, The greening of the corner office interviewed Francis McGuire, CEO of Major Drilling Group International Inc., a drilling service company in Montreal. He is quoted: "Unless you have legislative guidelines or targets spelled out, it's very hard for industry to get organized. [...] It's always better when the government sets down the rules. We need that" (Blackwell, 2007). Julie Dill, president of Union Gas Ltd. in Ontario, who was interviewed regarding the necessary actions in order to regulate greenhouse gas emissions and move towards sustainability, stated that "the government does have to step in" (Blackwell, 2007).

Several other articles in the Globe and Mail showed similar sentiments. From the Edmonton Journal, an article titled Building industry needs green vision contained an interview with a managing partner at the Windmill Development Group, a company which constructs green buildings, who commented that "Canada's building sector is like a 'rudderless ship' on the issue of greenhouse gas emissions" (Munro, 2008). The article discussed the need for government--led action in order to successfully green current practices in the construction industry.

\subsubsection{The Role of Energy Sources}

Common throughout the different newspapers was the discussion of alternative energy sources such as solar, wind, and hydro as solutions. As well, many articles mentioned and gave credit to green inventions, such as the compact fluorescent bulb. An article in the National Post contained an interview with Ray Tomalty, principal of Smart Cities Research Services and an adjunct professor in the School of Urban Planning at McGill University, who discussed "smart grids", which distribute green energy according to individual household use (Bitti, 2010). Another article discussed the actions Ford has taken to develop more fuel efficient vehicles which emit less greenhouse gas emissions (Fletcher, 2002).

The Globe and Mail offered several articles on the use of alternative fuels and the actions being taken internationally. In an article written by a journalist who was also a chartered financial analyst, Fabrice Taylor, discussed the move to use natural gas as an alternative to oil and coal. Taylor wrote that "You simply cannot green the planet without substituting gas for coal and oil" (Taylor, 2009). From the Globe and Mail, an article discussed the use of coal as "the fuel of the future", and the best alternative to replace the use of oil (Reynolds, 2009).

Ways to be green were presented throughout the articles in the newspapers, demonstrating a positive attitude towards greening behaviours by offering solutions, including solutions such as carbon capture and storage. The most prevalent greening method related to energy mentioned was carbon capture and storage, which was dubbed "the holy grail of environmental progress in the oil and gas industry" (Sankey, 2008). Articles provided explanations: "oil sands emissions are captured, then moved by pipeline to old oil fields around Edmonton, where the gas would be injected to increase oil recovery while the carbon would be effectively permanently stored" (Ebner, 2007) and opinions: "Developing viable carbon capture and storage technology is a key to greening both Alberta's and Canada's growth" according to Alberta Energy Minister Mel Knight (Jaremko, 2008). The articles were filled with praise for carbon capture and storage, suggesting the method had "tremendous promise in "greening" fossil fuels" (Schmidt, 2009). Various articles provided figures for the amount the government (both provincial and federal) was providing: "Alberta has pledged $\$ 2$ billion to kick-start capturing and storing carbon emissions from coal power plants, heavy-oil upgraders, and potentially the oilsands" (Schmidt, 2009). The media portrayed carbon capture and storage as the ultimate solution to climate change, transferring this ideal to the public. The use of natural gas was often mentioned in passing as an alternative to oil; however few articles went into depth about the positive and negative implications of its use. There was one article which was centered on the topic, claiming: "They call natural gas the 'champagne' of fossil fuels for a reason" (Taylor, 2009), and discussing the figures which illustrate that the use of gas was significantly greener: "As far as electrical generation is concerned, gas emits as much as 50 per cent less carbon dioxide as coal. Compared with gasoline burned in cars, it's as much as 30 per cent cleaner with respect to carbon emissions and 
90 per cent cleaner as far as nitrous oxide is concerned" (Taylor, 2009). Another article discussed the recent (2010) legislature which was passed making it mandatory for gasoline to contain 5\% ethanol in Alberta. The article stated that the new legislation "is expected to help reduce $\mathrm{CO}_{2}$ emissions by about one million tonnes a year" (Audette, 2008). Natural gas was portrayed as a green product, but the effects of its use were not explained. Two articles discussed the transportation of natural gas, and both are part of a series titled. The greening of Inuvik: As talk of pipelines escalates, Inuvik is juggling a booming economy with its corresponding influx of people and their need. These two articles went in-depth regarding the potential development of a pipeline to transport natural gas which would start in Alaska and follow along the Alaska Highway (Struzik, 2001a, 2001b). These articles did not discuss the environmental implications of the pipeline.

Throughout the articles a range of greening practices were discussed, suggested, and criticized. The most common topic was individual actions such as riding a bike or taking transit and replacing "incandescent light bulbs with compact fluorescents" (Barrie-Anthony, 2005). As well, oil and gas was mentioned in the discussion of 'greened': "The environment will sigh with relief when we can buy our gasoline knowing its production has been 'greened"" (Thompson, 2007). These actions included individuals in government: "Alberta legislators have set to work recycling paper and cutting out foam coffee cups from their daily routines" (Helm, 1991). There were also many household-level ideas presented in the articles, such as having wool carpets and "super-efficient windows" (Langston, 2010). Methods which small businesses had taken to green their business included adding " $\$ 200,000$ worth of extra sprinklers installed (that's 1,200 heads) to be more precise in how the course gets watered, minimizing wasted irrigation" (Farquharson, 2009) and using solar panels. The articles also discussed the methods bigger businesses were using to go green: "Ford will begin to roll out its EcoBoost range of four-and six-cylinder engines. The adoption of gasoline direct injection and turbocharging improves fuel economy by $20 \%$ or more while dropping $\mathrm{CO}_{2}$ emissions by $20 \%$ without diminishing overall performance" (Fletcher, 2008). More unusual greening practices which were discussed include Stonyfield Farm's changing of what they feed the cow in order to decrease the animal's flatulence, and thus decrease the release of the greenhouse gas methane (Reynolds, 2009). Overall, articles provided a range of greening methods for individuals, households, and small businesses, however in the oil and gas sectors the focus of the greening discourse was on oil extraction and the superficial/surface mentions of the green benefits of using natural gas.

The practices and methods mentioned as being able to be used to achieve the greening of oil and natural gas distinctly focused on the extraction stage. According to the National Post, there was "\$3.4 million in funding" which was all aimed at developing biological and mechanical technology that would provide "new methods of extraction" (Sankey, 2008). There was also discussion regarding making the use of water during extraction more sustainable; oil companies would reuse "groundwater instead of surface water by recycling it back into the system after treating it" (Sankey, 2007). As well, the issues with land destruction during extraction came up: "Shell, in partnership with federal government scientists, has developed new technology to use less energy to remove sand and other debris from oil sands during processing" (Ebner, 2007). The particular methods used to bring the oil to the surface during extraction were also discussed, such as the use of underground reactors, which according to an article in The Globe and Mail were "the next step for the oil sands, where the materials injected into in-situ wells would do more than carry bitumen to the surface: they could partly process the oil underground, resulting in a higher-grade product. This could significantly cut both the amount of natural gas needed to power the process and the emissions kicked out into the atmosphere" (Ebner, 2007).

One article discussed the transportation of oil (hits for "pipeline": National Post $\mathrm{n}=4$; Globe and Mail n= 14; Edmonton Journal $\mathrm{n}=53$; Calgary Herald $\mathrm{n}=15$ ) after it is extracted. The transportation of "tonnes of gooey Venezuelan bitumen by pipeline without the use of an expensive diluent" (Harding, 2006) was discussed in an article which contrasted the oil production methods in Canada to those in Venezuela. There was very little discussion regarding the greening of the transportation phase. There was literally no discussion on the aftermath of oil extraction, aka the cleanup and revival of the land, after production is finished. One article, Greenpeace antics give pause for thought, in the Edmonton Journal, briefly mentioned the restoration of tailings ponds when discussing an ad campaign created by the Alberta government (Thomson, 2010a). That is the only mention of restoration at all.

\subsection{Issue of Linkage to Other Topics}

As we outlined before the economy is the main linkage in all of the articles. However other linkages exist such as to water issues $(42 \%)$, the term 'global' $(27.09 \%)$, waste $(26 \%)$, climate change $(25.8 \%)$, growth $(19.7 \%)$, footprint (18\%), health $(16.4 \%)$, regulation $(11.5 \%)$, risk (10.8\%), education $(9.9 \%)$, the term 'Kyoto' $(8.6 \%)$, mining (5.4\%), transport (4.8\%), agriculture (3.6\%) and defense (4.7\%) and Keystone XL-pipeline (1.5\%). To highlight some issues around linkages we cover below a few of the linkages further. 


\subsubsection{The Term 'Kyoto'}

The term 'Kyoto' is one example for a term whose peak distribution mimics the peak distribution of our articles. Although the term Kyoto does only show up in $8.6 \%$ of the articles in all four newspapers the second peak around Kyoto fits with the second peak around greening time-wise. No newspaper covered Kyoto when the first greening peak occurred. However the amount covered is quite another story. Within the 2006-2009 greening peak in the Globe and Mail Kyoto was mentioned in 19 articles. At the same time the overall numbers of article mentioning Kyoto were 1200. If we add the search term 'energy' to the articles covering Kyoto 485 still remain. If we then replace the term energy with greening only 19 articles remain for this 2006-2009 period. This indicates that the greening articles made much less of a connection to Kyoto then articles that cover energy. This is if we look at absolute numbers. If we look for $\%$, then $2.2 \%$ of the Globe and Mail articles that covered energy from 2006-2009 also covered Kyoto whereas 1\% of the Globe and Mail articles that covered greening from 2006-2009 also covered Kyoto. As for the Calgary Herald the ratio was 1.5\% versus 7\% indicating that the relative coverage of Kyoto was greater in the greening articles then in the energy articles. As for the National Post the ratio was $7 \%$ versus $5.7 \%$ and the Edmonton Journal was $2.0 \%$ versus $3.5 \%$.

\subsubsection{The Term 'Global'}

The term 'global' is a good example for a term being diluted. As to concepts linked to the term 'global' global warming was the most frequently occurring term. The Edmonton Journal mentioned it 19 times with a peak 1990-1991 and the second peak mirroring the second peak of greening 2006-2009. This pattern of it mimicking the 2006-2009 peak of our articles in general was also true for the Calgary Herald $(\mathrm{n}=15)$ and the Globe and Mail $(\mathrm{n}=31)$ whereas the National Post the term was more spread out between 2006-2011 with the highest number in $2006(\mathrm{n}=14)$. As to $\%$, the numbers ranged between $1-2 \%$ for the four newspapers. The two terms of global economy and global economic were mentioned 19 times. However in general, many different phrases related to "global" were present in the four newspapers with very few showing up repeatedly: global temperature (related to climate change) $(n=4)$, global climate change $(n=4)$, global conflict $(n=3)$, global leader $(n=3)$, global environmental questions $(n=3)$, global market $(n=2)$, global growth rate $(n=2)$, global competitiveness $(n=2)$, global investment in sustainability $(n=2)$, global downturn $(n=2)$, global effort to reduce emissions $(n=2)$, global organics industry $(\mathrm{n}=2)$ and only once the phrases global despair over ecological terrorism, global household energy use, global commitment, global politics, global commons, global poster child in regards to bad environmental habits due to the oilsands, global credit crisis, global crisis, global food markets, global cycles, global oil and gas, global petroleum show, global sustainability, global sustainable energy market, global sustainability related legislation, global trade, global catastrophes, global reserves of cooper, global threat by pollution and waste, global co-ordination, global shock, global greening, global quest for energy security (China), global industry project, global player (China), global order (America, natural place in the global order -- as the beacon of progress, hope and inspiration), global greenhouse gas emissions, global food production, global pollution, global green-coal industry, global lottery of wealth, postglobal world, global citizen, global electricity use, global weather pattern, global science initiative, global marketing, global responsibility, global influence, global arms-control, global success, global environmental movement, global negotiation on an international treaty, global supply chain, global food system, global financial crisis, global respect, positive global force in climate change (China), global carbon dioxide emission, global market meltdown if not dealing with climate change.

\subsubsection{The Issue of Risk}

We highlighted earlier that most of the articles had a positive take on greening and that greenwashing a term used to highlight one form of negative sentiment towards the implementation of greening was little covered. Fitting with this reality is the fact that only 16 in the Calgary Herald, 9 articles in the Edmonton Journal, 23 articles in the Globe and Mail and 15 articles in the National Post used the term risk. Not only was the term risk used infrequent it also was used to describe all kind of risk issues and as such was as diluted as the term 'global'. The Calgary Herald's narrative around risk covered the risk energy companies face, the risk associated with nuclear energy, Obama's climate bill not moving on, being an early adopter of building a new green house, the University defending the building of carbon capture and storage facilities, risk to Alberta of gaining wealth, decrease in risk of going green with buildings and increasing risk linked to designing inefficient and unhealthy buildings, and risk with Alberta carbon trading markets. The Edmonton Journal mentioned that it might be risky if aboriginal groups own 100 per cent of a pipeline, Syncrude being at risk "of more malicious ducks staging anti-oilsands protests" (Thomson, 2010b), risk of climate related weather going haywire, and carbon risk a business has. One article from 2009 is titled, "Here comes carbon-constrained world; One trend will see investors demand to know how businesses plan to manage the risks of climate change" (Dixon, 2009). In 2008 
one article talked about Premier Harper banning exports of raw bitumen and that he can do this because there is no political risk for Premier Harper in antagonizing Albertans (Simons, 2008).

In 2008 a Globe and Mail article stated: "A study in the Proceedings of the National Academy of Sciences lists nine global "tipping elements" - regions that could experience abrupt climate change. At risk are the Amazon rain forest, boreal forest, West Antarctic and Greenland ice sheets, Arctic summer ice, Indian and African monsoons, Atlantic ocean currents and El Nino/Southern Oscillation cycles"(Cormier, 2008). Other risks mentioned in the Globe and Mail were that coastal properties become more risky, risks of floods, risk of desertification, public understanding of science is at risk, polar bears, butterflies, Mauritanian mosques, Spanish churches and the graveyards of Arctic whalers are at risk, risk of higher taxes and stronger regulations for oilsand developers, risk of global pandemics, climate change and food crisis, risk zone for a political party in Sweden, insurance risk, risk of batteries and prescription medication to water supplies, "risk of governments playing leapfrog with standards as an element of trade strategy" (1990), risk of car racing becoming irrelevant, risk management and Green Centre Canada assuming the risk. The National Post mentioned environmental risk of climate change, too little is known about risk of carbon, risk of underground burial of carbon dioxide, risk to clean tech, spilt oil risk, risk of crop failure, environmental risky, and plants at risk.

\subsubsection{The Issue of Regulation}

The term 'regulation' showed up in $\mathrm{n}=22$ articles of the Calgary Herald; in $\mathrm{n}=23$ articles of the Edmonton Journal; in $\mathrm{n}=39$ articles of the Globe and Mail and $\mathrm{n}=15$ articles of the National Post. Seven articles mentioned the term more than once, while the rest mentioned it only one time. It is an example for the case of coverage being all over the place (too little, too much).

As to regulations, the Calgary Herald wrote in the article CPA did much to prepare oilpatch for 'green' era in 1990:

"The oil and gas industry has been doing its environmental homework for years and now - faced with threats of massive, costly, new government regulation - the energy business has mounted a well-prepared public relations blitz. The readiness of the oilpatch to meet environmental issues head- on is due, in no small part, to Ian Smyth and the Canadian Petroleum Association. CPA president Smyth says that energy companies have had active environmental programs for 20 years, "but in 1984 I began to proselytize that if the industry wanted to continue to do business, it was going to have to earn public trust and that meant performance across the industry as a whole" (Nelson, 1990).

A 2010 article highlighted that "As part of a new pro-oilsands public relations campaign, the Stelmach government will run a newspaper ad today in the Winnipeg Free Press to coincide with the premiers meetings. The ad encourages Canadians to embrace the oilsands and stresses the Alberta government has regulations to protect land, water and people" (Fekete, 2010a). One article quoted a federal minister saying "In a pointed speech to Calgary business leaders, Prentice said Canada won't adopt a cap-and-trade emissions reduction program or regulations for specific industries like the oil-patch, unless the U.S. -the country's largest trading partner -decides to go that route" and setting cap-and-trade against regulation and Canadian Association of Petroleum Producers applauded the move" (Fekete, 2010b).

One 2009 article highlighted that the wind industry feels enough regulated and others want to regulate them more (Cryderman, 2009b). One article quoted the UNEP report "Global Trends in Sustainable Energy Investments" which stated that there is an increasing regulatory support for renewable energy. Another article talked about carbon capture storage: "government and industry strategy to green the image of Alberta's oilsands and delay regulations that would crack down on pollution" (De Souza, 2011). One article stated: "federal environment commissioner said the Harper government's greenhouse gas regulations don't stand up to scrutiny. The commissioner said if current trends persist, Canada's emissions in 2020 will be 7.5 per cent higher than they were in 2005 - not 17 per cent lower, as Ottawa had committed" (Cryderman, 2012). The Edmonton Journal mentioned the Liberal Leader Michael Ignatieff asking for stronger regulation of the oilsands, and that Tories prefer regulations on industry to control emissions. The article "Charges took too long, activist says; Shows Alberta has Third World environmental rules" gave voice to Alberta people as to the usefulness of environmental rules (Anonymous, 2009). One article (2007) talked about increase in pollution in China due to unregulated growth and another (2007) talks about China generating environmental regulations. Articles highlighted views that regulations are not needed (Achenbach, 2006), that they are needed (Riley, 2007), and that existing ones are behind the times (Simpson, 2008). As to the Globe and Mail sentiments covered were that regulation will come if behavior does not change (Raymond, 1990a), risk of more regulation (DeCloet, 2008) and "regulatory measures must make best practices mandatory, reward innovation and ensure that innovators 
profit" (Das, 2010). Similarly one 2007 opinion piece by Preston Manning, an influential conservative Canadian politician in recent times, stated, "The principal alternative to heavy-handed regulation as a means of conserving the environment is to effectively harness market forces and mechanisms to the task" (Manning, 2007). One 2007 article (Blackwell, 2007) reported that a C-Suite Survey conducted for the Report on Business and Business News Network "shows a strong regional divide, with Western executives - particularly those in the natural resource sector - much less enthusiastic than bosses in the East when it comes to controversial measures such as restricting oil sands growth or imposing a tax on carbon use". Another article stated, "business is motivated to change by the fears of regulation and poor corporate image but, above all, it will respond to consumer pressures" (Picard, 1990). As to the National Post these two quotes highlight their sentiment well:

"While these environmental issues complicate business planning for Canadian entrepreneurs, several strategies make sense: Investigate and take advantage of subsidies and incentives designed to boost energy and operating efficiency; stay current on environmental requirements and proposed changes; anticipate tougher regulations and higher emissions and effluent charges when making longer-term investments; and at a macro level, watch for business opportunities in environmental remediation and energy efficiency - areas that are bound to be growth leaders in the next decade" (Warren \& Webb, 2007).

"In response to public pressure, politicians, the industry and regulators have begun to invest heavily in environmental technologies and training so the next generation of energy and environmental professionals will be equipped to deal with the challenges of developing the massive energy reserves in Canada in an environmentally friendlier way" (Sankey, 2008).

\subsubsection{Keystone XL-pipeline}

The Keystone XL-pipeline is one example for a topical energy issue not being discussed within the greening discourse. The Keystone XL-pipeline, a pipeline to bring unrefined oilsand bitumen from Alberta Canada to refineries in the South of the USA (Cherry, 2011) has been a divisive topic for some time but especially in recent months. However no greening article mentioned the Keystone XL-pipeline in the National Post despite 434 articles in the National Post in general mentioning the Keystone XL-pipeline. The results for the other three newspapers are 3 versus 322 for the Globe and Mail, 4 versus 601 for the Calgary Herald and 3 versus 461 for the Edmonton Journal. Now to look at it from a different angle, $71 \%$ of the general Keystone articles mention the term energy but only 3 mention the term greening. The numbers for the Calgary Herald are (77\%/4), for the Edmonton Journal $(71 \% / 4)$ and for the National Post $(67 \% / 0)$. That the linkage to greening is not made is interesting given that the idea is put forward by some that the pipeline is greener than alternative transports such as trains and ships (Horn, 2012).

\section{Discussion}

When comparing the four newspapers, a few conclusions can be reached. In regards to salience, all four newspapers saw the topic of greening as it relates to energy issues as important in the same timeframes with two peaks evident (peak 1 1989-1992; peak 2 2006-2009). The interest in the topic in 2013 is on the base level, meaning very little interest is evident. Furthermore if we look at total numbers, although $88 \%$ of the articles that covered greening also have the term energy present, only $0.15 \%$ of the articles that cover energy in general also had greening in them. This suggests a general lack of interest in covering greening related to energy topics not only in recent years but also in the peak years. This is problematic given that green energy is seen as a cornerstone of green and sustainable development and a green and sustainable society (OECD, 2012). Our findings suggest that the four newspapers are not a source of information that allow citizens to gain information in such a way that they can be informed and active citizens in the process of greening energy. This suggests that a retooling of the media coverage is needed as well as how organizations involved in greening of energy discourses get their message out.

Keeping aside the general lack of coverage, there are other implications of the greening coverage of energy issues. Ahchong and Dodds in their analysis of climate change coverage in two Canadian newspapers (Globe and Mail and the Toronto Star) concluded that climate change was mostly portrayed as a large scale issue in need of large scale solutions; they concluded that this might discourage the public and government to look for solutions on regional and local levels and on the level of the individuals (Ahchong \& Dodds, 2012). As to the geographical scope of the greening issue, we found that our four newspapers saw greening as an international, national and local issue with many articles focusing on the local and national level at the same time. When comparing the national newspapers (National Post and Globe and Mail) to the Albertan newspapers (Calgary Herald and Edmonton Journal) in regards to coverage of leadership, the Albertan newspapers discussed leadership on a local level, including small business owners and citizens while the national papers generally tend 
to stick to national and international government leaders. This suggests that readers of the national newspapers we covered might be more prone to the problem Ahchong and Dodds highlighted in their analysis namely that readers might not see themselves as being part of the solution. However, we suggest that readers of the two local newspapers we covered are well primed to think about small-scale solutions and actions. They on the other hand might not see the global consequences of their local actions. This suggests that people might need to read local and national newspapers regularly in order to have the local and global connections and be able to look at the topic from a glocalized (Ángeles Murga-Menoyo, 2009; CERFE, 2003; Joseph \& Ramani, 2012; Kraidy, 1999; Robertson, 1995), global-local interdependency perspective.

As to topics linking to climate change covered by the media, Ahchong and Dodds found strong linkages to international cooperation, energy, transportation and science research and development. They found little linkages to agriculture, defense, education, health, land and water management, economy or social order (Ahchong \& Dodds, 2012). Our articles reflect quite different linkages; Ahchong and Dodds did not see a linkage to economic issues whereas in our case this linkage was present in nearly every article with $100 \%$ of the articles in the National Post and the Edmonton Journal mentioning business and around $50 \%$ mentioning business in the Calgary Herald and the Globe and Mail. Whether an article is exhibiting an opinion questioning or promoting greening, the discussion is based not on environmental factors but on economics. The newspapers display very little incentive to act more sustainably for the sake of the environment. Thus, the general public who rely on media for information will be motivated almost entirely by profit. Our findings as to the economic linkage also was found by Young and Dugas who investigated the media analysis of global warming in Canada using the National Post and the Globe and Mail; "less attention is paid to issues of causation, scientific claims, and potential impacts, while more attention is granted to how climate change superficially intersects with everyday politicking and business issues" (Young \& Dugas, 2011). Our analysis also revealed linkages to among others health (16.4\%) and water issues (42\%) which Ahchong and Dodds did not see. On the other end, very little concrete examples of international co-operation were mentioned in our articles (to give one example, "Canada, along with Brazil, Colombia, Mexico, the United States and Venezuela, will collaborate on clean energy research to reduce the impact of fossil fuel development" (Anonymous, 2010) whereas that was seen as a main linkage to climate change by Ahchong and Dodds. Similar to Ahchong and Dodds, we found little linkage to agriculture (3.2\%), defense (4.7\%) or education (9.9\%). We suggest that one of the implications of not making the linkage to education hinders the generation of active and competent citizens that can actively shape the discourse. It also means that a reader of the newspaper will not gain a feeling of whether a change in education practices is needed. Furthermore quite a few of the linkages such as to the term 'global' revealed an unfocused coverage making it nearly useless in giving guidance to the reader as to the consequences of greening or not greening and the actions the reader could or should not take.

As to the scope of voices present, the government was seen as important, as are businesses. However, Inuit's, people from Inuvik and Aboriginal People, First Nation People, and Indigenous Peoples were the least mentioned despite the fact that they have views on energy extraction and its effect on their lives. We submit this invisibility needs to be changed.

It is well known that journalists influence media delivery and also often set agendas and that journalists are influenced by their environment (Allport \& Faden, 1940; Bulkow et al., 2013; Carragee \& Roefs, 2004; Illia et al., 2013; McCauley et al., 2013; Reese, 2001; Shoemaker et al., 2008; Sill et al., 2013; Tilley \& Hollings, 2008; Weaver \& Elliott, 1985). Ahchong and Dodds and Liu found that the regional newspapers they investigated (Toronto Star and Houston Chronicle) both covered little local and regional content but mostly national and International content related to climate change (Ahchong \& Dodds, 2012; Liu et al., 2008). Our two local newspapers presented a lot of local content which seems to be different from the findings of Ahchong and Dodds and Liu.

As to visibility of 'fright factors' investigated in other media analyses (Abdelmutti \& Hoffman-Goetz, 2009; Bennett, Calman, \& Curtis, 2009; Burke, 2012; Deignan et al., 2013; Ekberg, 2007; Granatt, 2004; Meara, 2002; Verbeke, Frewer, Scholderer, \& De Brabander, 2007), they were very little present in the newspapers we covered; for the most part we observed that articles especially from the Edmonton Journal and the Calgary Herald have a very upbeat tone regarding greening and are about businesses and individuals who are 'greening' their actions. However, it is not quite clear how much of an impact this upbeat coverage has especially as the economic factor was so evident. What if an economic benefit is not that clear in certain interventions, or what about interventions that are not having a short term economic benefit? If people get influenced to think about greening in economic terms they might be easily turned off if the benefit might only be appearing over the long term. On the other hand, especially in the two local newspapers, so many issues are covered over time that the 
bigger picture is getting lost. One quote in the Calgary Herald raises this flag. According to Jennifer Jacquet of Vancouver, author of the Guilty Planet blog, who is interviewed in the Calgary Herald, "It is totally confusing consumers. There's very little trust (from the public) in corporations. People want to do the right thing, but when people think they're buying something that's more ecofriendly because of some eco-endorsement or the green packaging and then they find out it isn't more eco-friendly, they get confused and frustrated" (Edwards, 2010). This quote suggests that action is needed in diminishing the confusion of the public as this confusion is not only hurting the push for more greening in general but also individuals and companies who want to green. They are especially hurt if the economic argument is a main driver for greening because greening can only be sustained if there is a consumer. This suggest that companies and NGO's and others might be more vigilant and vocal in outing the ones who just greenwash. The same is true for the four newspapers. A more critical coverage of greening might be needed that not only supports greening but also outs more greenwashing practices.

Natural resources are discussed frequently, as opposed to alternative sources of energy. Green energy and energy sources which are seen as green are discussed significantly less. This indicates that there is more emphasis put on greening the energy sources currently being used, rather than turning to alternative energy sources. This suggest that the media sentiment is more useful for companies who are involved in hydrocarbon based energy extraction processes than for companies that want to build up non-hydrocarbon based green energy sources in Canada. Given that both approaches are needed for a green economy in the short term, this suggests that the groups that want to increase non-hydrocarbon based energy in Canada have to find a different way to get their message out or have to convince the media of them being newsworthy. Many experts, citizens, and small business owners were quoted in the newspaper articles demanding government action. This suggests that more government action is needed although from the articles it is not clear what should be done first or even what should be really done by the government. Development of indicators for greening were recently initiated by the OECD which has "developed a conceptual framework for monitoring progress towards green growth, and for identifying relevant indicators" (OECD, 2012) (see also (OECD, 2011)). It comprises of "four inter-related groups of indicators that capture the main features of green growth: the environmental and resource productivity of production and consumption; the natural asset base; the environmental dimension of quality of life; the policy responses and economic opportunities" (OECD, 2012) which is complemented by indicators that describe the socioeconomic context and characteristics of growth (OECD, 2012). The OECD perceives the following as determinants of green growth:

Environmental and resource productivity (to capture the need for efficient use of natural capital and to capture aspects of production which are rarely quantified in economic models and accounting frameworks) (OECD, 2011).

Economic and environmental assets (to reflect the fact that a declining asset base presents risks to growth and because sustained growth requires the asset base to be maintained) (OECD, 2011).

Environmental quality of life (capturing the direct impacts of the environment on people's lives, through e.g. access to water or the damaging effects of air pollution) (OECD, 2011).

Economic opportunities and policy responses (which can be used to help discern the effectiveness of policy in delivering green growth and where the effects are most marked) (OECD, 2011).

UNEP also is in the process of developing indicators. "UNEP defines a green economy as one that results in improved human well-being and social equity, while significantly reducing environmental risks and ecological scarcities" (UNEP, 2012). The indicators from UNEP cover three areas indicators of economic transformation, indicators of resource efficiency and indicators of societal progress and well-being (UNEP, 2012) whereby the last set of indicators cover many areas covered by the Millennium Development Goals (UNEP, 2012) and social sustainability goals. The 25 'headline indicators' proposed (OECD, 2011, 2012) and the indicators proposed by UNEP (UNEP, 2012) might be a start for action however from the media coverage the reader would have no idea that such indicators exist (indeed the term indicator only showed up once in all articles we looked at) and the reader would make very few linkages to the societal aspect of green growth and the linkage between greening of energy and development in its various facets. This is a glaring omission that needs to be rectified.

\section{Conclusion}

Our study revealed that although $88 \%$ of newspaper articles that covered greening also covered energy issues, only $0.15 \%$ of the articles that covered energy issues also contained the term greening. This suggests that in the moment the four newspapers might not be the source for looking at the area of greening as it relates to energy. Greening was mostly framed in economical not environmental protection terms which might limit the ideas of actions the newspaper articles trigger in their readers. Very little was found about the effect of business practices 
on environmental performance and the role of governments and non-governmental agencies in aiding the effect of sustainable business practices. Indeed it's not really clear what governments should do although the articles reflect that various stakeholders want the government to do something. The expectations of the government seem to go in all directions; for example more regulation, less regulation and keeping status quo in regards to regulations were all expectations reported with no consensus evident on the topic of action. This makes it difficult for people and business to act on greening if they do not know what they face and what help they might get or what hurdles they might face in the short term and long term. Many themes were covered but often only once in a given article and often in less than $10 \%$ of the overall articles; most articles were news items with very few letters to the editors or opinion and analysis pieces limiting the utility of the reading material. We submit that more in depth analysis pieces are needed. A hierarchy of voices was evident in the four newspapers something we believe is limiting the utility of the information further. Greening indicators are developed in various places (e.g. (OECD, 2011, 2012) and (UNEP, 2012)). Media could play a leading in fostering this discussion. However, in order for this to occur media coverage has to change in quantity and quality.

\section{Acknowledgments}

This work was in part supported by a Genome Canada and Genome Alberta research grant.

\section{References}

Abdelmutti, N., \& Hoffman-Goetz, L. (2009). Risk messages about HPV, cervical cancer, and the HPV vaccine Gardasil: a content analysis of Canadian and US national newspaper articles. Women \& Health, 49(5), 422-440. http://dx.doi.org/10.1080/03630240903238776

Abroms, L. C., \& Maibach, E. W. (2008). The effectiveness of mass communication to change public behavior. Annu. Rev. Public Health, 29, 219-234. http://dx.doi.org/10.1146/annurev.publhealth.29.020907.090824

Achenbach, J. (2006, June 4). The stormy world of climate-change skeptics. Edmonton Journal, p. E6.

Ahchong, K., \& Dodds, R. (2012). Anthropogenic climate change coverage in two Canadian newspapers, the Toronto Star and the Globe and Mai, from 1988 to 2007. Environmental Science \& Policy, 15(1), 48-59.

Allenby, B. R. (1994). The greening of industrial ecosystems. National Academies Press.

Allport, G. W., \& Faden, J. M. (1940). The Psychology of Newspapers: Five Tentative Laws. Public opinion quarterly, 4(4), 687-703. http://dx.doi.org/10.1086/265448

Anderson, A. (2009). Media, politics and climate change: towards a new research agenda. Sociology Compass, 3(2), 166-182. http://dx.doi.org/10.1111/j.1751-9020.2008.00188.x

Ángeles Murga-Menoyo, M. (2009). The Earth Charter. A reference for the decade of education for sustainable development. La Carta de la Tierra: Un referente de la década por la educación para el desarrollo sostenible(SPEC. ISSUE), 239-262.

Anonymous. (2007, June 21). Capital flowing into alternative energy; Legislation main impetus behind move, Calgary Herald, p. E5.

Anonymous. (2008, May 1). Rockefellers go public about greening Exxon Mobil; Founder's descendants want company to further pursue alternatives to oil. Edmonton Journal, p. F2.

Anonymous. (2009, February 10). Charges took too long, activist says; Shows Alberta has Third World environmental rules. Edmonton Journal.

Anonymous. (2010, April 17). Heavy oil green group formed. Calgary Herald, p. C4.

Arnold, M. G., \& Hockerts, K. (2010). The greening dutchman: Philips' process of green flagging to drive sustainable innovations. Business Strategy and the Environment. http://dx.doi.org/10.1002/bse.700

Audette, T. (2008, December 12). Farmers cheer province's new biofuel strategy; Move will see 5\% ethanol at pump by 2010. Edmonton Journal, p. B5.

Baer, W. S., Geller, H., Grundfest, J. A., \& Possner, K. B. (1974). Concentration of Mass Media Ownership: Assessing the State of Current Knowledge. Retrieved from http://www.rand.org/pubs/reports/R1584.html

Barrie-Anthony, S. (2005, March 5). House greening made easy. Edmonton Journal, p. J6.

Benford, R. D. (1997). An Insider's Critique of the Social Movement Framing Perspective*. Sociological Inquiry, 67(4), 409-430. http://dx.doi.org/10.1111/j.1475-682X.1997.tb00445.x

Bennett, P., Calman, K., \& Curtis, S. (2009). Risk communication and public health. Oxford University Press. 
Beun-Chown, J. (2009, April 22). It's all about ecology and economy; Saving Cash, National Post, p. SR3.

Bitti, M. T. (2010, August 17). Turning the grid into an info highway. National Post, p. FP13.

Blackwell, R. (2007, March 26). The greening of the corner office. The Globe and Mail, p. B1.

Blackwell, S. (1997). The Private Energy Elite: How the Energy Foundation has Abandoned Environmentalists and Used Big Money to Greenwash the Private Utility Industry, Energy Foundation (on file with. Loyola Consumer Law Review, 2.

Bosselman, F. (2011). Green diesel: Finding a place for algae oil. Chi.-Kent L.Rev., 86, 291-419.

Brooymans, H. (2009, January 14). Green energy timeline 20 years. Edmonton Journal, p. A3.

Bruno, K., \& Karliner, J. (2000, April 22). Watch out for greenwash. Calgary Herald, p. O7.

Bulkow, K., Urban, J., \& Schweiger, W. (2013). The Duality of Agenda-Setting: The Role of Information Processing. International Journal of Public Opinion Research, 25(1), 43-63. http://dx.doi.org/10.1093/ijpor/eds003

Burke, D. C. (2012). There'sa long, long trail a-winding: The complexities of GM foods regulation, a cautionary tale from the UK. GM Crops and Food: Biotechnology in Agriculture and the Food Chain, 3(1), 30-39. http://dx.doi.org/10.4161/gmcr.18041

Carragee, K. M., \& Roefs, W. (2004). The neglect of power in recent framing research. Journal of Communication, 54(2), 214-233. http://dx.doi.org/10.1111/j.1460-2466.2004.tb02625.x

CERFE. (2003). Glocalization: Research Study and Policy Recommendations. Retrieved from http://www.cpi.hr/download/links/en/4297.pdf

Cherry, C. (2011). Keystone Pipeline: Environmentally Just, The. Envtl. \& Energy L. \& Pol'y J., 6, 125.

Cherry, M., \& Sneirson, J. (2010). Beyond profit: Rethinking corporate social responsibility and greenwashing after the BP oil disaster.

Coppolecchia, E. K. (2010). The Greenwashing Deluge: Who Will Rise Above the Waters of Deceptive Advertising? U.Miami L.Rev., 64, 1353-1505.

Cormier, Z. (2008, February 16). Holy orders: Give up carbon for Lent. The Globe and Mail (Index-only), p. F7.

Cryderman, K. (2008a, May 25). PR pro advice costs Tories \$35K, Calgary Herald, p. A1.

Cryderman, K. (2008b, December 29). Syncrude duck deaths cap oilpatch's 'dirty' year, Calgary Herald, p. A3.

Cryderman, K. (2009a, July 1). Critics see holes in CO2 plan; Health care comes first, say Liberals. Calgary Herald, p. F1.

Cryderman, K. (2009b). Wind farm worries; Turbine project gives rise to health concerns. Calgary Herald, p. B1.

Cryderman, K. (2012, May 18). Climate strategy back on drawing board; Alberta admits missing target to cut emissions. Calgary Herald, p. A1.

Das, S. (2010, January 4). Greener oil sands, greener planet. The Globe and Mail, p. A15.

De Souza, M. (2010, July 20). Gov't fails at going green, study finds. Edmonton Journal.

De Souza, M. (2011, March 30). Carson changed research mandate; Greening the oilsands' image became focus. Calgary Herald, p. A6.

De Vreese, C. H. (2005). News framing: Theory and typology. Information design journal+ document design, 13(1), 51-62.

DeCloet, D. (2008, February 26). Why Big Oil discovered its love of trees. The Globe and Mail, p. B2.

Deignan, B., Harvey, E., \& Hoffman-Goetz, L. (2013). Fright factors about wind turbines and health in Ontario newspapers before and after the Green Energy Act. Health, Risk \& Society (ahead-of-print), 1-17.

Deng, M. M., \& Liu, L. J. (2011). The Analysis and Discussion about Green Supply Chain Management of Oil Industry in China. Applied Mechanics and Materials, 65, 32-35. http://dx.doi.org/10.4028/www.scientific.net/AMM.65.32

Dinica, V. (2008). Greening Electricity Production: A Success Story of Multi-Level Governance Convergence and Innovation. Energy \& Environment, 19(6), 787-801. http://dx.doi.org/10.1260/095830508785363596 
Dixon, R. (2009, November 11). Here comes carbon-constrained world; One trend will see investors demand to know how businesses plan to manage the risks of climate change. Edmonton Journal, p. A17.

Dong, G., Fan, H., \& Zhang, X. (2011). Influencing factors analysis of low-carbon green development of China's oil ports. Journal of Dalian Maritime University (Social Science Edition), 4.

Dornfeld, D. (2010). Sustainable ManufacturingGreening Processes, Systems and Products. Retrieved from $\mathrm{http}: / /$ escholarship.org/uc/search?keyword=greening\&entity=lma_gmg

Ebner, D. (2007, January 6). The greening of the oil sands. The Globe and Mail, p. B4.

Edmonton Journal. (2000, October 11). Living Proof. Edmonton Journal, p.G1.

Edwards, T. (2010, July 23). Ecoetiquette; Why you should tread lightly when offering green living tips to friends and family, Calgary Herald, p. C8.

Ekberg, M. (2007). The Parameters of the Risk Society A Review and Exploration. Current Sociology, 55(3), 343-366. http://dx.doi.org/10.1177/0011392107076080

El Chaar, L., \& Lamont, L. A. (2010). Nourishing green minds in the land of oil. Renewable Energy, 35(3), 570-575. http://dx.doi.org/10.1016/j.renene.2009.08.015

Energy Consumption Rating Initiative. (2008). Energy Efficiency for Network Equipment: Two Steps Beyond Greenwashing. White Paper, August, 10.

Entman, R. M. (1991). Symposium Framing US Coverage of International News: contrasts in narratives of the KAL and Iran Air incidents. Journal of communication, 41(4), 6-27. http://dx.doi.org/10.1111/j.1460-2466.1991.tb02328.x

Farquharson, V. (2009, September 24). The newest greening of golf. National Post, p. AL10.

Fekete, J. (2010a, August 5). Economy dominates premiers' meeting. Calgary Herald, p. A1.

Fekete, J. (2010b, February 2). Environment minister calls for oilsands cleanup. Calgary Herald, p. A1.

Fekete, J., \& D'Aliesio, R. (2008, April 16). Tories focus on Alberta growth; Throne speech outlines vision for economy. Calgary Herald, p. A1.

Fletcher, G. (2002, February 16). The greening of cars best left to the hybrids: Infrastructure for fuel cells could take years to implement. National Post, p. DO10.

Fletcher, G. (2008, May 2). Ford unveils green future. National Post, p. DT11.

Frank, C. (2008, August 16). Oilsands face uphill battle in PR war; An industry under fire needs a new plan of attack if it is to protect Alberta's interests. Calgary Herald, p. D1.

Gallicano, T. D. (2011). A Critical Analysis of Greenwashing Claims. Public Relations Journal, 5(3).

Gieg, L. (2011). How Specific Microbial Communities Benefit the Oil Industry: Case Study ÇôProof of Concept that Oil Entrained in Marginal Reservoirs Can Be Bioconverted to Methane Gas as a Green Energy Recovery Strategy. Applied Microbiology and Molecular Biology in Oilfield Systems, 193-198.

Gilens, M., \& Hertzman, C. (2000). Corporate ownership and news bias: Newspaper coverage of the 1996 Telecommunications Act. Journal of Politics, 62(2), 369-386. http://dx.doi.org/10.1111/0022-3816.00017

Good, J. E. (2008). the framing of climate change in Canadian, American and international newspapers: A media propaganda model analysis. Canadian Journal of Communication, 33(2).

Granatt, M. (2004). On trust: Using public information and warning partnerships to support the community response to an emergency. Journal of Communication Management, 8(4), 354-365. http://dx.doi.org/10.1108/13632540410807745

Harding, J. (2006, April 3). Going deep, staying deep. National Post, p. FP1.Fr.

Helm, R. (1991, January 9). Legislature slowly takes on cleaner, greener look. Edmonton Journal, p. A6.

Heras-Saizarbitoria, I., Cilleruelo, E., \& Zamanillo, I. (2011). Public acceptance of renewables and the media: an analysis of the Spanish PV solar experience. Renewable and Sustainable Energy Reviews, 15(9), 4685-4696. http://dx.doi.org/10.1016/j.rser.2011.07.083

Horn, S. (2012). Warren Buffett Exposed: The Oracle of Omaha and the Tar Sands. Retrieved from http://www.desmogblog.com/warren-buffett-exposed-oracle-omaha-and-tar-sands

Illia, L., Lurati, F., \& Casalaz, R. (2013). Situational Theory of Publics: Exploring a Cultural Ethnocentric Bias. 
Journal of Public Relations Research, 25(2), 93-122. http://dx.doi.org/10.1080/1062726X.2013.758581

Islam, R., Chhetri, A. B., Khan, M. M., \& Islam, M. R. (2010). The Greening of Petroleum Operations: Wiley Publisher. http://dx.doi.org/10.1002/9780470922378

Iyengar, S. (1994). Is anyone responsible?: How television frames political issues: University of Chicago Press.

Jaremko, G. (2008, February 1). Carbon price tag $\$ 2$ billion; Gov't cash needed for greenhouse gas reducing projects, task force says. Edmonton Journal, p. D1.

Jonas, G. (2011, April 27). What price green energy?, National Post, p. A15.

Joseph, A., \& Hughes, L. (2006). The Challenge of Greening Energy Systems. Paper presented at the International Green Energy Conference, University of Ontario Institute of Technology. Retrieved from http://dclh.electricalandcomputerengineering.dal.ca/enen/2006/ERG200611.pdf

Joseph, M., \& Ramani, E. (2012). Glocalization: Going Beyond the Dichotomy of Global Versus Local Through Additive Multilingualism. International Multilingual Research Journal, 6(1), 22-34. http://dx.doi.org/10.1080/19313152.2012.639246

Koeller, J., \& Gauley, B. (2009). Sustainability: The Great Energy Greenwash. Electrical Connection (Autumn Quarter 2009), 42.

Koenig, T. (2004). Routinizing frame analysis through the use of CAQDAS. Paper presented at the RC33, Amsterdam, Amsterdam, The Netherlands. Retrieved from http://www.restore.ac.uk/lboro/research/methods/routinizing_frame_analysis_RC33.pdf

Kraidy, M. M. (1999). The global, the local, and the hybrid: A native ethnography of glocalization. Critical Studies in Media Communication, 16(4), 456-476. http://dx.doi.org/10.1080/15295039909367111

Langston, P. (2010, October 16). How to navigate through the environmental hype; The top seven trends for greening your home. Edmonton Journal, p. I12.

Leahy, S. (2013). Report: Canada Could be a Green Energy Goliath. Retrieved from http://www.desmog.ca/2013/03/27/report-canada-could-be-green-energy-goliath

Liu, X., Vedlitz, A., \& Alston, L. (2008). Regional news portrayals of global warming and climate change. Environmental Science \& Policy, 11(5), 379-393. http://dx.doi.org/10.1016/j.envsci.2008.01.002

MacMillan, K. (2005). More than just coding? Evaluating CAQDAS in a discourse analysis of news texts. Forum Qualitative Sozialforschung/Forum: Qualitative Social Research, 6(3), Art. 25

Magness, V. (2012). Legitimacy in Green: Pollution vs. Profit in Canadian Oil Refineries. Issues in Social and Environmental Accounting, 1(1), 54-71.

Maier, C. D. (2011). Communicating business greening and greenwashing in global media: A multimodal discourse analysis of CNN greenwashing video. International Communication Gazette, 73(1-2), 165. http://dx.doi.org/10.1177/1748048510386747

Mair, J., \& Jago, L. (2009). The development of a conceptual model of greening in the business events tourism sector. Journal of Sustainable Tourism, 18(1), 77-94. http://dx.doi.org/10.1080/09669580903291007

Manning, P. (2007, January 11). The way to gain green ground. The Globe and Mail, p. A19.

Marotte, B. (2008, February 25). Wild green yonder? A 747 fueled partly by coconuts. The Globe and Mail, p. A3.

Martin, D. (2007, February 13). Big Oil too easy a target. Calgary Herald, p. A4.

Mathisen, W. C. (2006). Green utopianism and the greening of science and higher education. Organization \& Environment, 19(1), 110-125. http://dx.doi.org/10.1177/1086026605285242

McCauley, M., Blake, K., Meissner, H., \& Viswanath, K. (2013). The social group influences of US health journalists and their impact on the newsmaking process. Health Education Research, 28(2), 339-351. http://dx.doi.org/10.1093/her/cys086

McLaren, D. (2008, November 26). Measuring the good global citizen. The Globe and Mail, p. B18.

McLean, A. (2010, June 15). Alberta warns U.S. fuel standards law bad for environment. Calgary Herald, p. A6.

Meara, J. (2002). Getting the message across: is communicating risk to the public worth it? Journal of Radiological Protection, 22(1), 79. http://dx.doi.org/10.1088/0952-4746/22/1/308 
Mitchell, P. A. (2011). Life cycle thinking (LCT) implementation: a new approach for'greening'industry and providing supply chain information: a plywood industry study, $\mathrm{PhD}$ Thesis. Retrieved from http://espace.library.uq.edu.au/view/UQ:107172

Munro, M. (2008, March 14). Building industry needs green 'vision'; Report urges aggressive goals to cut emissions. Calgary Herald, p. A13.

Nelson, B. (1990, April 21). CPA did much to prepare oilpatch for 'green' era. Calgary Herald, p. B8.

Ng, A. F. (2010). An/other Bell Ringing in the Sky: Greenwashing, Curriculum, and Ecojustice. Journal of the Canadian Association for Curriculum Studies, 8(1), 41-67.

Niederdeppe, J., Farrelly, M. C., Thomas, K. Y., Wenter, D., \& Weitzenkamp, D. (2007). Newspaper Coverage as Indirect Effects of a Health Communication Intervention The Florida Tobacco Control Program and Youth Smoking. Communication Research, 34(4), 382-405. http://dx.doi.org/10.1177/0093650207302784

Nodoushani, O., \& Nodoushani, P. A. (2010). The greening of entreprenourship: An examination of small business strategy. Business Research Yearbook, 17(1), 220-226. Retrieved from http://blue.utb.edu/lfalk/2010V1BRY.pdf\#page=233

OECD. (2011). Towards Green Growth: Monitoring Progress: OECD Indicators: OECD Publishing.

OECD. (2012). Energy, OECD Green Growth Studies: OECD Publishing.

Parker, D. (2006, February 23). The greening of Canada's ski resorts. Calgary Herald, p. F7.

Parlour, J. W., \& Schatzow, S. (1978). The mass media and public concern for environmental problems in Canada, 1960-1972. International Journal of Environmental Studies, 13(1), 9-17. http://dx.doi.org/10.1080/00207237808709800

Pearce, F. (2009, 26 March). Greenwash: Shell betrays 'new energy future'promises, The Guardian. Retrieved from http://www.guardian.co.uk/environment/2009/mar/26/fred-pearce-greenwash-shell-exxon

Petersen, L. K. (2013). Ecological Footprints in transnational media. Retrieved from http://pure.au.dk/portal/files/53254297/EcoFoot_in_media_workingpaper.pdf

Picard, A. (1990, October 13). Turn green or wilt, business told Consumer pressure called key for firms to turn earth-friendly. The Globe and Mail, p. B6.

Plec, E., \& Pettenger, M. (2012). Greenwashing Consumption: The Didactic Framing of ExxonMobil's Energy Solutions. Environmental Communication: A Journal of Nature and Culture, 6(4), 459-476. http://dx.doi.org/10.1080/17524032.2012.720270

Price, C. J. (2003). Interfering owners or meddling advertisers: How network television news correspondents feel about ownership and advertiser influence on news stories. The Journal of Media Economics, 16(3), 175-188. http://dx.doi.org/10.1207/S15327736ME1603_3

Raymond, J. (1990a, March 9). Worth repeating The greening of pulp. The Globe and Mail, p. B2.

Raymond J. (1990b, February 28). Worth repeating The fall of unions. The Globe and Mail, p. B.2.

Reese, S. D. (2001). Understanding the global journalist: A hierarchy-of-influences approach. Journalism Studies, 2(2), 173-187. http://dx.doi.org/10.1080/14616700118394

Reynolds, N. (2009, August 26). The greening of coal, the fuel of the future. The Globe and Mail, p. B2.

Riley, S. (2007, June 22). There's a limit to how green an individual can be in wasteful economy; Being carbon neutral just one day a week is harder than expected. Edmonton Journal, p. A16.

Robertson, R. (1995). Glocalization: Time-space and homogeneity-heterogeneity. Global modernities, 25-44. http://dx.doi.org/10.4135/9781446250563.n2

Sampei, Y., \& Aoyagi-Usui, M. (2009). Mass-media coverage, its influence on public awareness of climate-change issues, and implications for Japan's national campaign to reduce greenhouse gas emissions. Global Environmental Change, 19(2), 203-212. http://dx.doi.org/10.1016/j.gloenvcha.2008.10.005

Sankey, D. (2007, April 18). Workers cash in on greening of the oilsands; Tech skills in demand. National Post, p. WK5.

Sankey, D. (2008, April 16). Greening Of The Patch. National Post, p. WK3.

Scheufele, D. A. (1999). Framing as a theory of media effects. Journal of communication, 49(1), 103-122. 
http://dx.doi.org/10.1111/j.1460-2466.1999.tb02784.x

Schmidt, L. (2009, February 20). Oilpatch cheers Canada-U. S. energy plan; Sector hopes for balance in green push. Calgary Herald, p. C4.

Schudson, M. (2002). The news media as political institutions. Annual review of political science, 5(1), 249-269. http://dx.doi.org/10.1146/annurev.polisci.5.111201.115816

Scott, A. (2011). Corporate Social Responsibility Greening the Supply Chain. Chemical Week, 173(8), 21-24.

Scott, M. (2008, March 3). Doing the Greenwash; So-called green products the latest trend in retail. Calgary Herald, p. C7.

Shaw, H. (2008, May 23). Green halo or green wash?; Claims about eco-friendly products are often met with suspicion. National Post, p. FP14.

Shoemaker, P. J., Vos, T. P., \& Reese, S. D. (2008). Journalists as gatekeepers. Eds. Karin Wahl-Jorgensen and Thomas Hanitzsch, Handbook of Journalism Studies. New York: Routledge, 73-87.

Sill, K. L., Metzgar, E. T., \& Rouse, S. M. (2013). Media Coverage of the US Supreme Court: How Do Journalists Assess the Importance of Court Decisions? Political Communication, 30(1), 58-80. http://dx.doi.org/10.1080/10584609.2012.737414

Simons, P. (2008, September 27). Harper's vow to ban exports of raw bitumen spectacularly rude; PM's 'poorly considered' cowboy act in Calgary--home of oil-industry honchos -- leaves Alberta Tories gobsmacked, Edmonton Journal, p. A19.

Simpson, J. (2008, April 25). The NDP talks the green talk, but others actually walk it. The Globe and Mail, p. A19.

Singh, D., \& Mathur, V. K. (2011). Greening of Supply Chain. Journal of the Management Training Institute, SAIL, Ranchi, 33 .

Skjølsvold, T. M. (2012). Curb Your Enthusiasm: On Media Communication of Bioenergy and the Role of the News Media in Technology Diffusion. Environmental Communication: A Journal of Nature and Culture, 6(4), 512-531. http://dx.doi.org/10.1080/17524032.2012.705309

Smith, J. (2005). Dangerous news: Media decision making about climate change risk. Risk Analysis, 25(6), 1471-1482. http://dx.doi.org/10.1111/j.1539-6924.2005.00693.x

Smith, N., \& Joffe, H. (2009). Climate change in the British press: the role of the visual. Journal of Risk Research, 12(5), 647-663. http://dx.doi.org/10.1080/13669870802586512

Sneirson, J., \& Cherry, M. (2011). Chevron, Greenwashing, and the Myth of'Green Oil Companies'. Journal of Energy, Climate, and the Environment, 3.

Soylu, K., \& Dumville, J. C. (2011). Design for environment: The greening of product and supply chain. Maritime Economics \& Logistics, 13(1), 29-43. http://dx.doi.org/10.1057/mel.2010.19

Stanislaw, J. A. (2010). Clean Over Green: Oil And Gas in a Low-Carbon Future. Pipeline \& Gas Journal, 237(2), 58-59.

Stauffer, P., Keating, G. N., Middleton, R. S., Viswanathan, H. S., Singh, R. P., Berchtold, K. A., . . Mancino, A. (2011). Greening Coal: Breakthroughs and Challenges in Carbon Capture and Storage. Environmental Science \& Technology. http://dx.doi.org/10.1021/es200510f

Stein, M. (2010, 2010). The Political Consequences of Greenwashing in Consumer Culture. Paper presented at the Western Political Science Association 2010 Annual Meeting.

Stephens, J. C., Rand, G. M., \& Melnick, L. L. (2009). Wind energy in US media: a comparative state-level analysis of a critical climate change mitigation technology. Environmental Communication, 3(2), 168-190. http://dx.doi.org/10.1080/17524030902916640

Stephenson, E., Doukas, A., \& Shaw, K. (2012). Greenwashing gas: Might a 'transition fuel'label legitimize carbon-intensive natural gas development? Energy Policy, 46, July 2012, 452-459. http://dx.doi.org/10.1016/j.enpol.2012.04.010

Strauss, S. (1997, December 5). Greening of economy measured. The Globe and Mail, p. A12.

Struzik, E. (2001a, August 26). The greening of Inuvik: As talk of pipelines escalates, Inuvik is juggling a booming economy with its corresponding influx of people and their needs. Calgary Herald, p. B13FR. 
Struzik, E. (2001b). The greening of Inuvik: As talk of pipelines escalates, the N.W.T. town is juggling a booming economy with its corresponding influx of people and their needs Series: Down the Mackenzie, Edmonton Journal, p. H1FRO.

Sundararajan, B. (2008). Greening coal. CIM Magazine, 3(6), 41-43.

Taylor, F. (2009, June 17). Pick natural gas for a greener planet, and fatter wallet. The Globe and Mail, p. B9.

Thompson, J. (2007, January 8). The colour green. The Globe and Mail, p. A14.

Thomson, G. (2010a, August 5). Greenpeace antics give pause for thought; Public increasingly in favour of greening of the oilsands. So why not do it? Edmonton Journal, p. A16.

Thomson, G. (2010b, May 1). Syncrude defence in duck disaster at odds with industry goals; Stelmach government offers puzzling contradiction of getting 'more aggressive' while taking little action. Edmonton Journal, p. A17.

Tilley, E., \& Hollings, J. (2008). Still stuck in “A love-hate relationship": Understanding journalists' enduring and impassioned duality towards public relations. Paper presented at the Proceedings of the ANZCA 2008 Conference, Wellington, NZ.

Todd, D. (2008, June 14). Congregations are greening the world over; Leaders urge changes from double-glazed stained-glass to reinterpreting Genesis. Edmonton Journal, p. B15.

Tong, X., Shi, J., \& Zhou, Y. (2011). Greening of supply chain in developing countries: Diffusion of lead $(\mathrm{Pb})$-free soldering in ICT manufacturers in China. Ecological Economics, 83, November 2012, 174-182.

Torrie, R. D. B., Tyler, B. M., Anderson, B., Marshall, D., Kadowaki, R., \& Whitmore, J. (2013). An Inventory of Low-Carbon Energy for Canada. Vancouver, Canada. Retrieved from http://www.desmog.ca/2013/03/27/report-canada-could-be-green-energy-goliath

UNEP. (2012). Green Economy Briefing paper Indicators. Retrieved from http://www.unep.org/greeneconomy/Portals/88/GE_INDICATORS\%20final.pdf

United Nations Conference on Sustainable Development (Rio+20). (2012). The future we want. United Nations Conference on Sustainable Development. Retrieved from http://www.un.org/en/sustainablefuture/

Van Alphen, K., van Voorst tot Voorst, Q., Hekkert, M. P., \& Smits, R. E. (2007). Societal acceptance of carbon

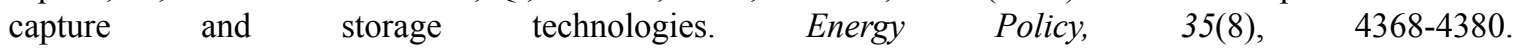
http://dx.doi.org/10.1016/j.enpol.2007.03.006

Verbeke, W., Frewer, L. J., Scholderer, J., \& De Brabander, H. F. (2007). Why consumers behave as they do with respect to food safety and risk information. Analytica Chimica Acta, 586(1), 2-7. http://dx.doi.org/10.1016/j.aca.2006.07.065

Warner, J. (2008). Have They Got the'Energy'for It?: Newly Found Morality of Modern Day Marketing?: Analysing the Prevalence of Greenwashing Amongst the World's Major Oil Producers. University of Sheffield.

Warren, J., \& Webb, M. (2007, April 16). Global greening can be boon; Scale and scope of initiatives opens opportunities, National Post, p. EN1.

Weaver, D., \& Elliott, S. N. (1985). Who sets the agenda for the media? A study of local agenda-building. Journalism Quarterly, 62(1), 87-94. http://dx.doi.org/10.1177/107769908506200113

Weingart, P. (2012). The Lure of the Mass Media and Its Repercussions on Science. The Sciences' Media $\begin{array}{llll}\text { Connection-Public Communication and } & \text { 17-32. }\end{array}$ http://dx.doi.org/10.1007/978-94-007-2085-5_2

Whitmarsh, L. E. (2005). A study of public understanding of and response to climate change in the South of England. University of Bath.

Winseck, D. (2002). Netscapes of power: Convergence, consolidation and power in the Canadian mediascape. Media, Culture \& Society, 24(6), 795-819. http://dx.doi.org/10.1177/016344370202400604

Young, C. E. F. (2011). Current trade trends in Latin America and the growth possibilities for greening the economy.

Retrieved

from http://www.ie.ufrj.br/images/gema/Gema_Artigos/2011/Young_2011_Green_Growth_EcoEco.pdf

Young, K. (2007, November 25). Rough road ahead for biofuel as green energy debate revs up; Only two E85 
pumps serve the 600,000 flex-fuel vehicles on Canadian roads, Edmonton Journal, p. A5.

Young, N., \& Dugas, E. (2011). Representations of climate change in Canadian national print media: The banalization of global warming. Canadian Review of Sociology/Revue canadienne de sociologie, 48(1), 1-22. http://dx.doi.org/10.1111/j.1755-618X.2011.01247.x

Young, S. (2012). Evolution advocate turns to climate. Nature, 481. http://dx.doi.org/10.1038/481248a

Zhao, X. (2009). Media Use and Global Warming Perceptions. Communication Research, 36(5), 698. http://dx.doi.org/10.1177/0093650209338911

\section{Copyrights}

Copyright for this article is retained by the author(s), with first publication rights granted to the journal.

This is an open-access article distributed under the terms and conditions of the Creative Commons Attribution license (http://creativecommons.org/licenses/by/3.0/). 